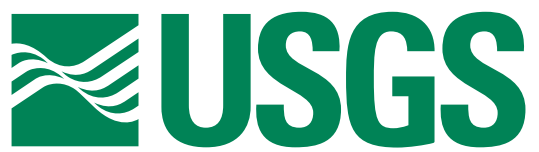

science for a changing world
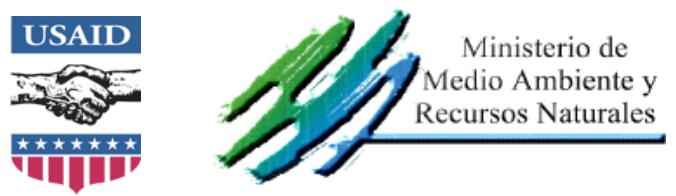

\title{
Landslides Induced by Hurricane Mitch in El Salvador- An Inventory and Descriptions of Selected Features
}

By Anthony J. Crone, Rex L. Baum, David J. Lidke, Damon N.D. Sather, Lee-Ann Bradley, and Arthur C. Tarr

Open-File Report 01-444

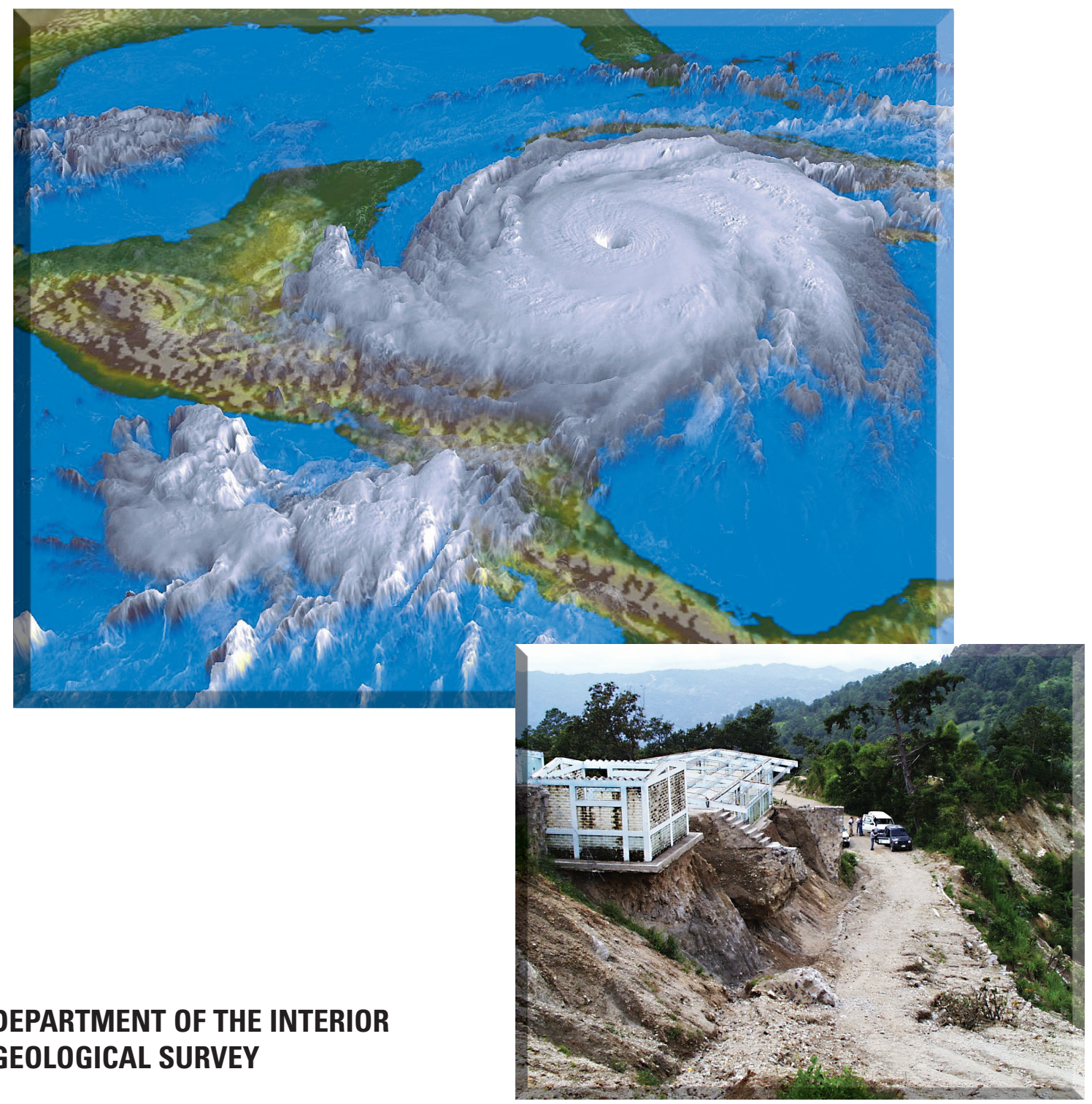




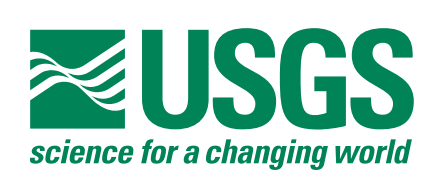

\title{
Landslides Induced by Hurricane Mitch in El Salvador- An Inventory and Descriptions of Selected Features
}

\author{
By Anthony J. Crone, Rex L. Baum, David J. Lidke, Damon N.D. Sather, \\ Lee-Ann Bradley, and Arthur C. Tarr
}

Open-File Report 01-444

(Spanish version available from USGS)

\section{1}

This report is preliminary and has not been reviewed for conformity with U.S. Geological Survey editorial standards or with the North American Stratigraphic Code. Any use of trade, firm, or product names is for descriptive purposes only and does not imply endorsement by the U.S. Government.

\section{U.S. DEPARTMENT OF THE INTERIOR U.S. GEOLOGICAL SURVEY}

Denver, Colorado 


\section{Contents}

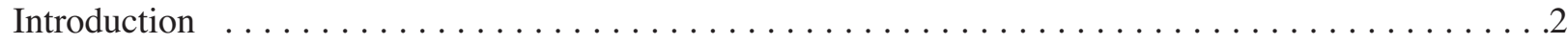

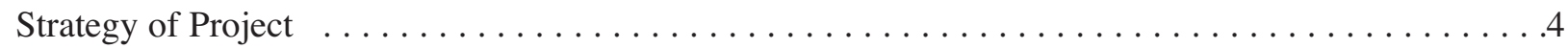

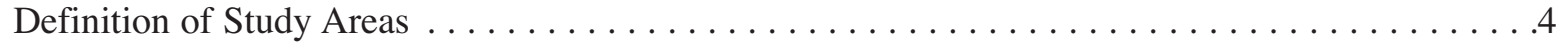

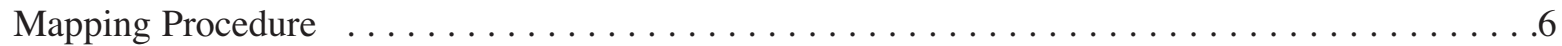

General Characteristics of the Storm-Induced Landslides $\ldots \ldots \ldots \ldots \ldots \ldots \ldots \ldots \ldots \ldots \ldots$

Aerial Photograph Observations and Interpretations $\ldots \ldots \ldots \ldots \ldots \ldots \ldots \ldots \ldots \ldots$

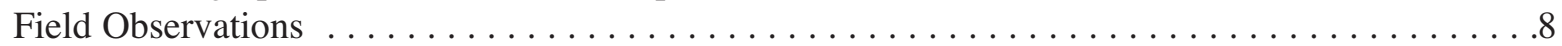

Description of Selected Features in Specific Study Areas $\ldots \ldots \ldots \ldots \ldots \ldots \ldots \ldots \ldots$

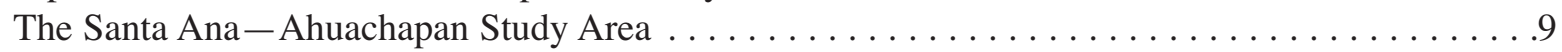

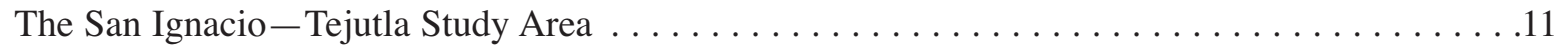

San Miguel-Berlin Study Area . . . . . . . . . . . . . . . . . . . . . . . . . 14

Summary of Hurricane Mitch Landslides and Overview of Landslide Hazards in El Salvador . . . . . .21

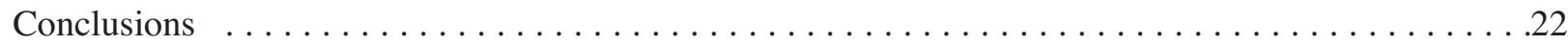

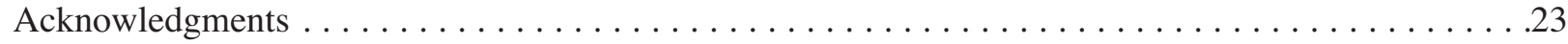

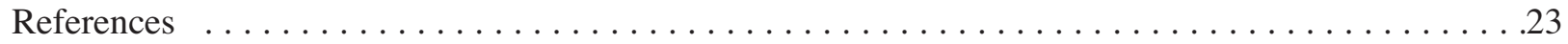

\section{Illustrations}

\section{Figure}

1 Satellite image of Hurricane Mitch on 26 October 1999 showing the well-defined eye of the storm

2 Schematic diagram showing the track of Hurricane Mitch in Central America and rainfall estimates from 25 October to 17 November 1998

3 General location map of El Salvador and the landslide study areas

4 View of one of several recent landslides in the area south and west of Lago de Coatepeque

5 View to the northeast of the upper part of El Zompopera landslide

6 View of the El Pinar landslide and the abandoned school

7 View of the western debris-flow channel and source area on Cerro El Coyote

8 View of the town of Guadelupe that was struck by a debris flow on 15 September 2001

9 Oblique aerial view of the main source area for the debris flow that occurred on 15 September 2001 on Volcán de San Vicente

10 Oblique aerial view of the debris flow on the northeast side of the town of Guadelupe that occurred on 15 September 2001

11 Partially overgrown scar of a shallow landslide in the area west of San Lorenzo

12 Scars of landslides caused by the 13 February 2001 earthquake west of San Lorenzo

13 Part of vertical aerial photograph showing recent debris flows on Volcán de Usulután

14 Scars of landslides on Volcán de Usulután triggered by the 13 February 2001 earthquake

15 Landslides inside the crater of Cerro El Taburete that were probably caused by the 13 February 2001 earthquake

16 Large dormant pre-hurricane landslide on the shore of Embalse 15 de Septiembre

17 Shallow landslide on the shore of Embalse 15 de Septiembre

18 Bank failure on the Río Gualcho about 4 km upstream of Embalse 15 de Septiembre 


\section{Plate}

\section{Maps of landslides triggered by Hurricane Mitch:}

1 Ahuachapan (2257 IV) Quadrangle

2 Southern half of the Santa Ana (2257 I) and northern half of the Sonsonate (2257 II) Quadrangles

3 Masahuat (2358 IV) and part of the Metapan (2359 III) Quadrangles

4 Northern half of the Tejutla (2358 I) Quadrangle and adjacent parts of Honduras (2359 II)

5 Southern half of the Tejutla (2358 I) and northern half of the El Paraiso (2358 II) Quadrangles

6 Chalatenango (2458 III) Quadrangle

7 Ilobasco (2457 IV) Quadrangle

8 Part of the Cojutepeque (2457 III), Rio Tithuapa (2457 II), San Vicente (2456 IV) and El Puente Cuscatalan (2456 I) Quadrangles

9 Part of the Rio Tithuapa (2457 II), Sensori (2557 III), El Puente Cuscatalan (2456 I), and Jucuapa (2556 IV) Quadrangles

10 Western part of the Berlin (2456 II), and part of the Usulután (2556 II) Quadrangles

11 Part of the San Francisco Gotera (2557 II), Jocoro (2556 I), San Miguel (2556 II), and La Union (2656 III) Quadrangles

Cover Photos: Hurricane Mitch approaching Central America on 26 October 1998, 13:15 UTC (07:15 local time). The hurricane is over the northern half of Nicaragua at this time. The image is derived from satellite data that has been color-enhanced and processed to yield a perspective rendering of the hurricane. Modified from image produced by Hal Pierce, Laboratory for Atmospheres, NASA Goddard Space Flight Center.

View of school house at El Pinar whose foundation was undermined by a landslide caused by Hurricane Mitch. Photograph by Anthony J. Crone, 21 September 1999. 


\title{
Landslides Induced by Hurricane Mitch in El Salvador- An Inventory and Descriptions of Selected Features
}

\author{
By Anthony J. Crone, Rex L. Baum, David J. Lidke, Damon N.D. Sather, \\ Lee-Ann Bradley, and Arthur C. Tarr
}

ABSTRACT Hurricane Mitch caused widespread flooding and landslides in four Central American countries in October and November 1998. Flooding was the most serious problem in $\mathrm{El}$ Salvador, but locally landslides caused damage and threatened people. As part of a USAID-supported recovery effort, we have compiled an inventory of landslides caused by the storm in areas that cover more than half of the country. We mapped the storm-induced landslides using aerial photographs taken shortly after the storm, and created a digital database of the landslide inventory and topographic maps. After completing the mapping from aerial photographs, we checked selected features in the field to better determine their characteristics. In addition to this report, the digital information generated by this study will be available on the world-wide-web through the Central American clearinghouse: (http://mitchnts1.cr.usgs.gov)

Virtually all of the storm-induced landslides are shallow failures that occurred mainly in unconsolidated surficial materials. In some cases, the failures became fluid enough to evolve into debris flows that traveled hundreds of meters to as much as several kilometers from their origins. The storm-induced landslides are scattered throughout the country, but the greatest concentration is in the mountainous area adjacent to San Ignacio near the Honduran border.
Scattered landslides also occurred in the Ahuachapan-Santa Ana region of western El Salvador, and in the San VicenteBerlin and San Miguel areas in eastern and east-central El Salvador. Only a few features appear to pose a continuing threat to villages or towns, but additional movement of some features could threaten roads and individual homes.

The largest landslide is $\mathrm{El}$ Zompopera, a large translational earth slide that evolved into a debris flow. This landslide existed before the hurricane, but the storm accelerated its movement. Deposits from this landslide-debris flow traveled more than $6 \mathrm{~km}$ from the slide's source.

The steep slopes of volcanoes and other mountainous terrain throughout El Salvador are susceptible to landslides, especially in areas where the underlying rocks are deeply weathered or extensively fractured. The information assembled in this landslide inventory can be used as a starting point for more comprehensive assessments of landslide hazards in the country. This inventory, when combined with bedrock geology and GIS-analyses of slope angles and slope-aspects, can be used to develop landslide susceptibility maps. Maps of landslide and debris-flow inundation zones can also be created, which provide valuable tools that can be used to guide future development and used to better prepare for future landslide emergencies. 


\section{Introduction}

$\mathrm{H}$ urricane Mitch began as a tropical depression on 21 October 1998 in the southern Caribbean Sea. As it moved westward, it strengthened into an intense storm (Figure 1) that by October 26th had sustained winds of 290 $\mathrm{km}$ per hour, gusts greater than $320 \mathrm{~km}$ per hour, and became the most deadly hurricane in the Atlantic Ocean in more than 200 years (Lott and others, 1999). The storm remained nearly stationary off the northeastern coast of Honduras for more than 24 hours and then moved slowly inland across Honduras and into western Nicaragua (Figure 2). The storm's slow movement produced heavy rain throughout Honduras and western Nicaragua, with less total precipitation in El Salvador and eastern Guatemala. As it moved onto land, it drew additional moisture from the Pacific Ocean, which supplemented the moisture already incorporated in the storm. The amounts of rain that fell during the storm are not accurately known, in part because few ground precipitation measurements are available (Hellin and Haigh, 1999). Analyses of satellite data indicate that the maximum rainfall was on the order of $800-1400 \mathrm{~mm}$ in western Nicaragua (Ferraro and others, 1999), although locally the amounts may have been as much as $1900 \mathrm{~mm}$ (Lott and others, 1999). The total rainfall in El Salvador was considerably less, and based on the map of Hellin and Haigh (1999), typical amounts appear to be on the order of $300-500 \mathrm{~mm}$ for much of the country (Figure 2). Hurricane Mitch was the strongest storm in the Caribbean Sea in more than a decade, and the abundant, intense rainfall caused widespread flooding and thousands of landslides in Honduras (Harp and others, 2002), Nicaragua (Cannon and others, 2001), Guatemala (Bucknam and others, 2001), and El Salvador.
Figure 1. Satellite image of Hurricane Mitch on 26 October 1998 showing the welldefined eye of the storm. Image is from National Oceanic and Atmospheric Administration (NOAA) and is available on the web at: http://www.osei.no aa.gov/Events/Trop ical/Atlantic/1998/ Mitch_10/TRCmitc h299B_G8.jpg.

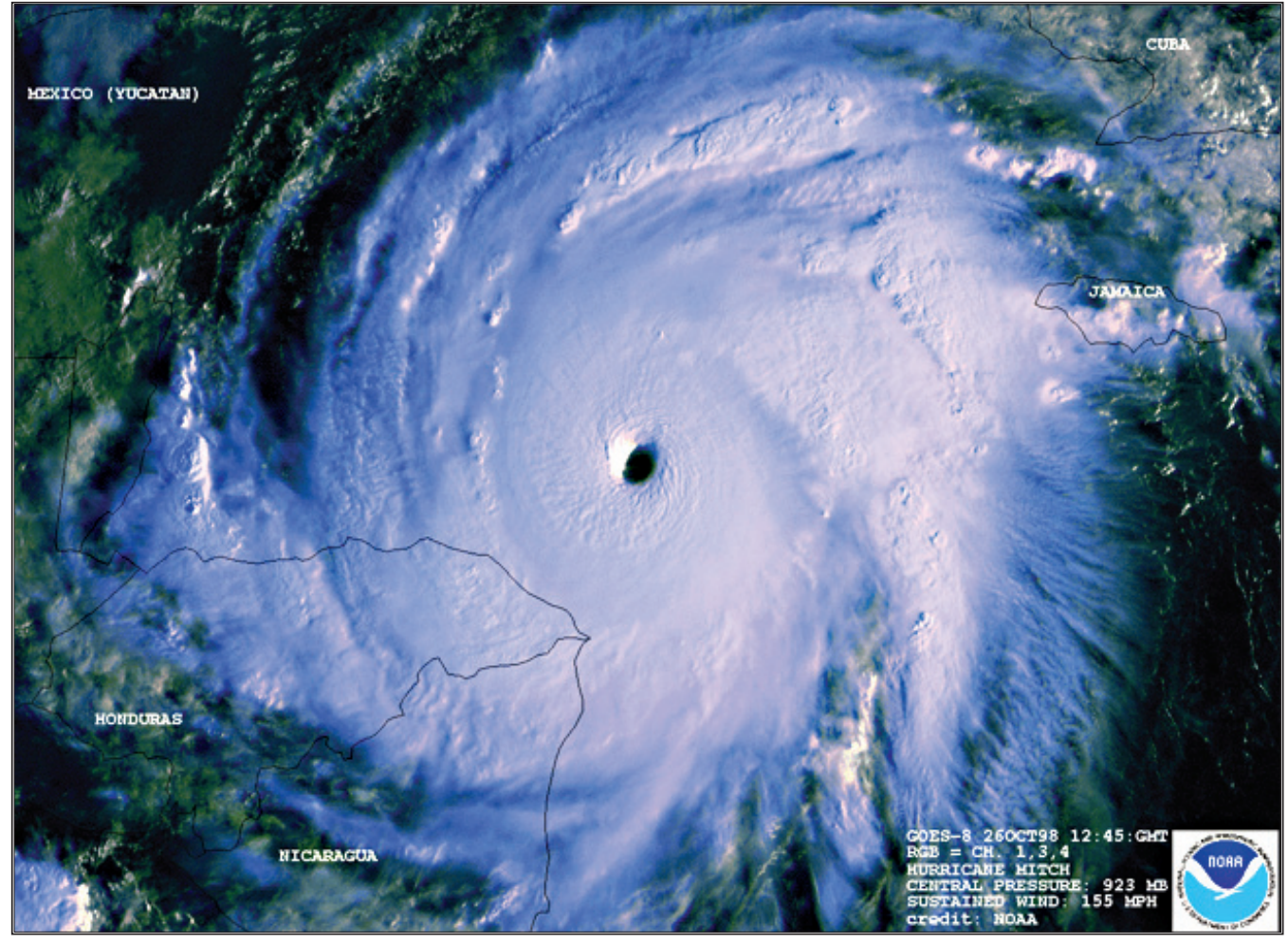




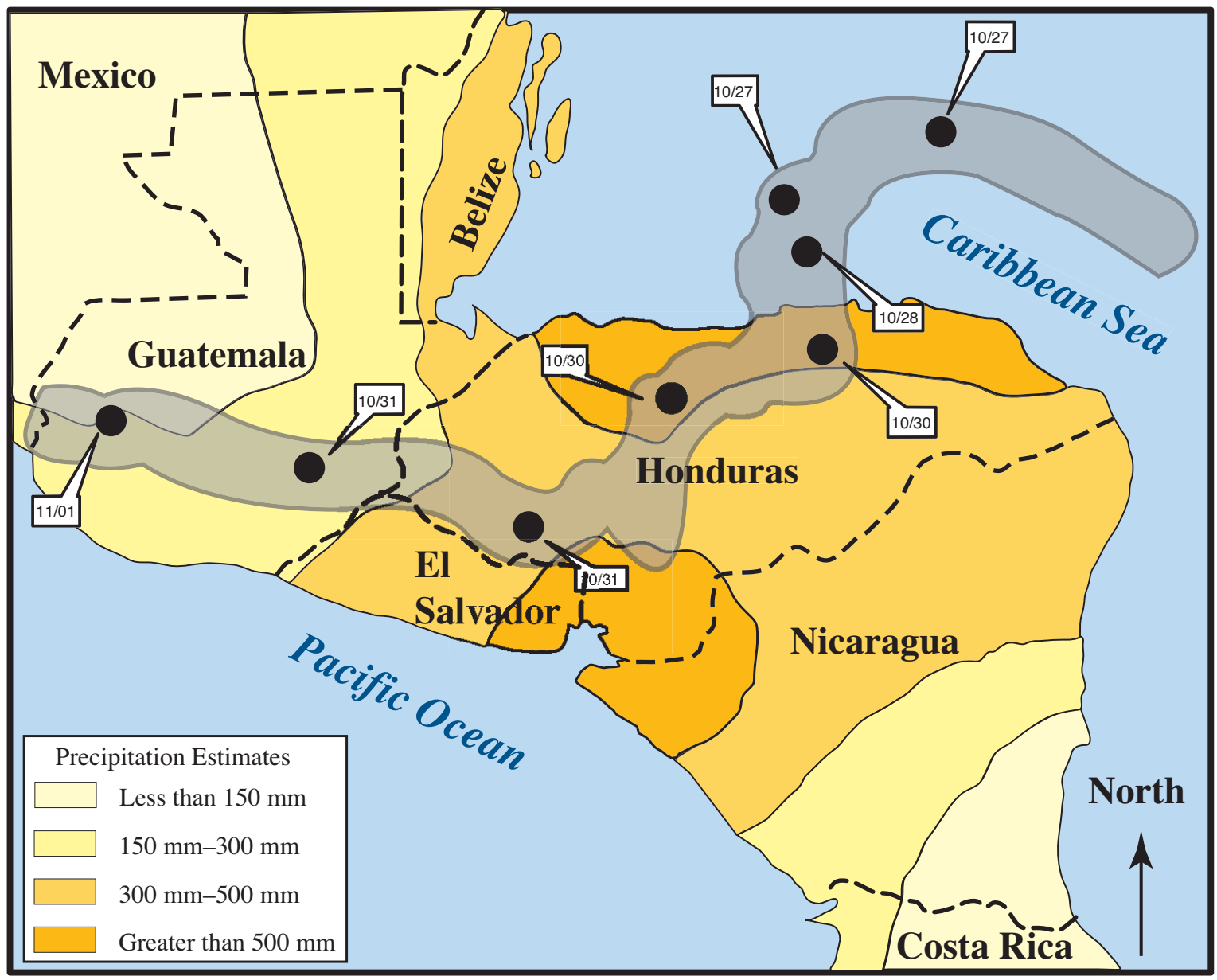

Figure 2. Schematic diagram showing the track of Hurricane Mitch in Central America and rainfall estimates from 25 October to 17 November 1998. Modified from Hellin and Haigh (1999).

Because of the storm's track, the most severe impacts were in Honduras and western Nicaragua, although extensive flooding and landslides occurred in parts of El Salvador and eastern

Guatemala. Rivers and streams flooded throughout the region, causing thousands of fatalities and the destruction of homes, roadways, bridges, and other infrastructure. Thousands of landslides added to the disaster, burying people, destroying property, and clogging drainages with huge volumes of fresh sediment. Along the coasts, the strong winds and huge influxes of fresh sediment from flooding rivers wreaked havoc on the delicate mangrove-forest and coral-reef ecosystems. Hurricane Mitch had a strong and lasting impact on the people, the infra- structure, the economies, and the landscapes in each of the four countries.

In El Salvador, rain from the hurricane fell on ground that was already saturated by previous precipitation, so the hurricane's rainfall raised rivers to record levels and caused extensive flooding, particularly in the lower reaches of the Río Lempa and in the Río Grande de San Miguel drainage in southeastern El Salvador (Figure 3). The Government of El Salvador (GOES) reported 374 deaths from the hurricane, and 55,800 people were displaced by the storm. In addition to the human toll, the storm caused more than $\$ 600$ million (U.S. dollars) in economic losses, damaged about 60 percent of the nation's paved roads, and prompted a multinational relief effort. 
As part of the multi-national effort to assist El Salvador, the United States Agency for International Development (USAID) took a lead role in identifying and fulfilling relief needs and implementing reconstruction plans. A key element of USAID's reconstruction effort was to avoid resettlement in hazard prone areas. As resettlement and reconstruction proceeded, the USAID mission in El Salvador (USAID/ES) supported studies to help identify sites where reoccupation would not expose people and structures to continuing natural hazards, including those posed by flooding, landslides, and volcanic eruptions. Scientists from the U.S. Geological Survey were engaged to evaluate these potential hazards in selected parts of El Salvador. This report and the accompanying maps are part of this broad effort to avoid hazardous sites.

\section{Strategy of Project}

\section{Definition of Study Areas}

The effects and impact of the hur-
ricane varied in different parts of El Salvador. In consultation with USAID officials in El Salvador and with colleagues and officials in various Salvadoran agencies, we initially defined three general areas where concerns existed about the occurrence and potential continuing impact of hurricane-induced landslides. When we defined these areas, information on significant landslides in El Salvador was somewhat incomplete, but based on the available information, we initially outlined three large study areas (Figure 3):

The Santa Ana-Ahuachapan study area, which encompasses approximately 2,600 $\mathrm{km}^{2}$ between Lago de Coatepeque on the east and Ahuachapan and the Río Paz along the Guatemalan border on the west (Plates 1 and 2).
Thus, the purpose of this inventory was to identify the locales of hurricaneinduced landslides so that their locations could be used to identify sites to be avoided in future resettlement efforts.

It is important to note that many factors affect the occurrence of landslides during rainstorms including the duration and intensity of the rainfall, the amount of moisture in the ground prior to the storm, the steepness and orientation of specific slopes, the nature of vegetation, and the characteristics and composition of soil and rock on slopes. Because the hurricane caused few landslides in a specific area does not mean that this area does not have a landslide hazard.

However, rare and intense storms such as Hurricane Mitch do help identify areas where future severe storms can trigger dangerous landslides.
The San Ignacio-Tejutla study area, which covers approximately $2650 \mathrm{~km}^{2}$ between Nueva Concepcion and El Paraiso on the south to San Ignacio and northward across the Honduran border (Plates 3, 4, 5, and 6).

The Berlin-San Miguel study area, which covers approximately $5000 \mathrm{~km}^{2}$ and extends from the eastern slopes of Volcàn San Miguel and the nearby volcanoes on the east to the western flank of Volcàn de San Vicente on the west (Plates 8, 9, 10, and 11).

These three initial study areas cover a total of about $10,250 \mathrm{~km}^{2}$, about 45 percent of the entire country.

Subsequent to defining the three original areas, two additional study areas were designated at the request of Salvadoran officials (Figure 3). These two additional areas, named the Embalse 

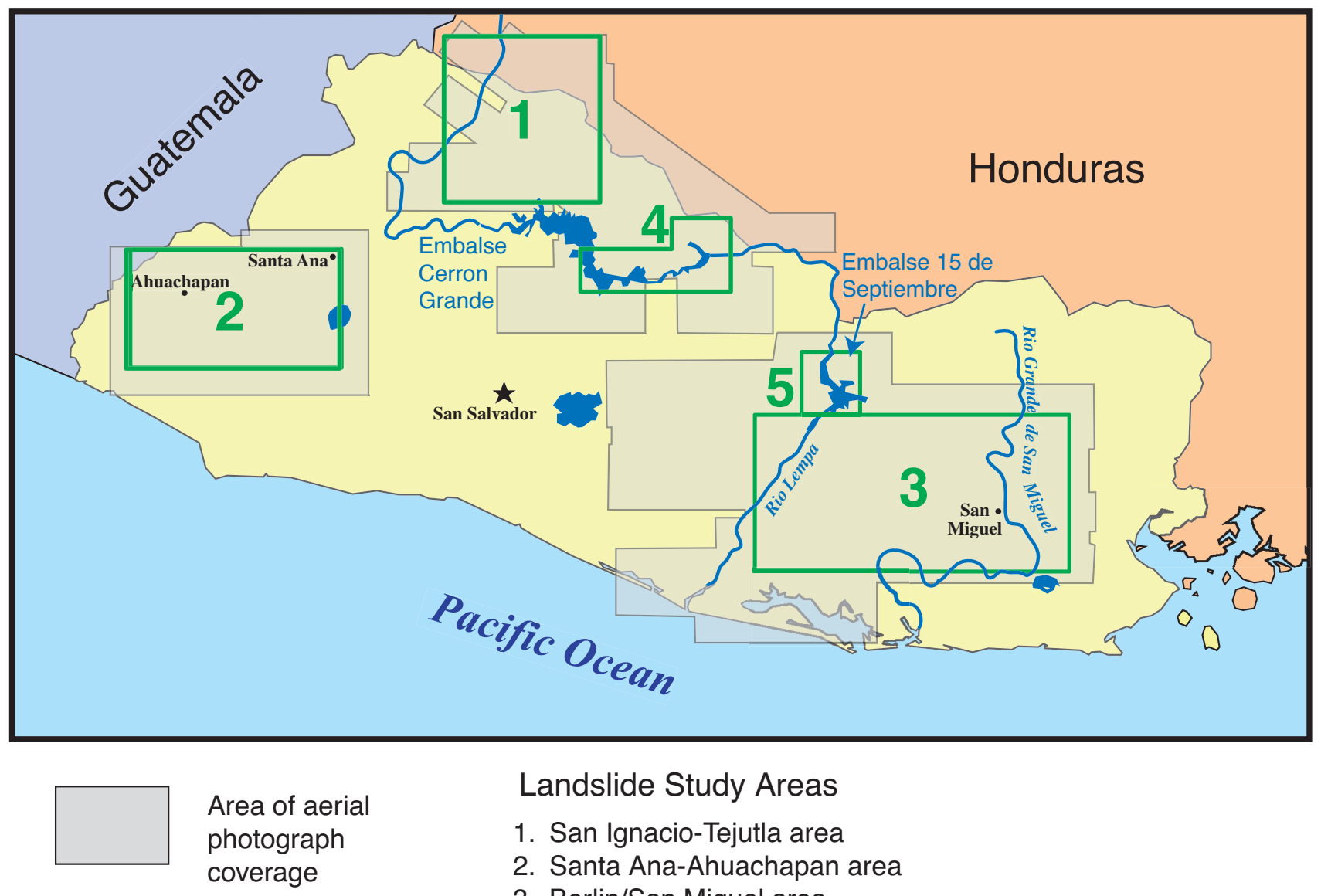

\section{Landslide Study Areas}

1. San Ignacio-Tejutla area

2. Santa Ana-Ahuachapan area

3. Berlin/San Miguel area

4. Embalse Cerron Grande

5. Embalse15 de Septiembre area

Figure 3. General location map of El Salvador and the landslide study areas. Areas 1, 2, and 3 were the initially defined study areas; areas 4 and 5 were added because of concerns about the possible effects of landslide on two large reservoirs Shaded areas show the coverage of aerial photographs that were examined in this study. Index maps on each plate show the areas where landslides were mapped in this study.

Cerrón Grande (Plate 7) and the Embalse 15 de Septiembre (Plate 9) study areas, were examined to assess the potential for landslides occurring in two of El Salvador's important reservoirs, whose stored water is an important source of the country's hydroelectric power. Our mapping in these areas identified only a few landslides in the vicinity of the reservoirs and no major failures that either threatened the hydroelectric facilities or their associated infrastructure. Furthermore, the few landslides near the reservoirs did not contribute any significant quantities of sediment to the reservoirs that would affect their capacity. These two added study areas covered an additional $1,240 \mathrm{~km}^{2}$, bringing the total coverage of the study areas to $11,490 \mathrm{~km}^{2}$, which is more than 50 percent of the entire country.

As we conducted our mapping, we expanded some of our mapping outside of our originally defined study areas to include areas where we had aerial photographic coverage (Figure 3). This expanded coverage is mainly around the eastern and southern margins of the San Ignacio-Tejutla study area in north-central El Salvador and in the Berlin-San 
Miguel area. Near the end of the project, we learned that Hurricane Mitch had triggered several significant and damaging landslides in the coastal range southeast

\section{Mapping Procedure}

\begin{abstract}
fter the study areas were defined, we used high-quality aerial photography to systematically examine the terrain, to identify and map recent slope failures, and to determine threats that they might pose to homes, roads, and infrastructure. The majority of our study areas were mapped using 1:40,000-scale, black-and-white photography that gave us stereographic coverage, but we also used 1:15,000-scale photography in a small part of the Santa Ana-Ahuachapan study area (Figure 3). All of our imagery was of high quality and largely cloud-free, but a few small areas that were concealed by clouds are shown on the accompanying plates.

Immediately after Hurricane Mitch in late 1998, the United States military flew several missions to collect high-altitude photography in the affected areas. This program, named "Open Skies," photographed extensive areas in Honduras, and parts of Nicaragua, Guatemala, and El Salvador (Molnia and Hallam, 1999). Unfortunately, most of the Open Skies imagery in El Salvador contains large amounts of cloud cover, making these photographs largely unusable for our purposes.
\end{abstract}

An important source of photography for our work was imagery flown by the Japanese International Cooperative Agency (JICA). These photographs covered most of the San Ignacio-Tejutla and the Cerrón Grande study areas, as well as a small part of the Berlin-San Miguel area. The hurricane-induced landslides are clearly visible on these images, some of which were taken a few months after the storm and others about one year after the hurricane. of San Miguel. Unfortunately, we did not have aerial photography of this area, so we could not expand our mapping to include these features.
In the northeastern and east-central part of the Ahuachapan-Santa Ana area, we utilized 1:15,000-scale black-andwhite photography that was taken in early 1999 by the Instituto Geográfico Nacional. The storm-induced landslides are clearly visible on these large-scale images because they were taken three months after the storm.

Our third source of photography was images acquired through a USGS contract to Aerophoto Centroamericana S.A. This photography filled gaps in the two previously described sets of photography. Because of logistical problems, contract delays, and poor weather, these 1:40,000scale images were not flown until the end of 2000. This lengthy delay between the time of the storm and acquisition of the photography covered two full growing seasons in which the vigorous tropical growth may have obscured some of the smallest landslides. As a result, we were unable to confirm that all the landslides we observed on the aerial photography actually resulted directly from Hurricane Mitch. In some areas, more recent storms that occurred between Hurricane Mitch and acquisition of the photography may have caused some of the mapped landslides, but we believe that virtually all of the features shown on the accompanying plates were related to the hurricane.

From the air photographs, we mapped the location and extent of landslides by visually inspecting the photographs using magnifying mirror stereoscopes. These stereoscopes provided sufficient resolution to identify features as small as about 2-3 $\mathrm{m}$ on the 1:40,000scale photographs. We visually trans- 
ferred landslides on the photographs to either 1:25,000- or 1:50,000-scale topographic base maps. Most of the features we mapped were clearly landslides associated with Hurricane Mitch, but we also identified a few features whose origin was unclear; during the field-review phase of our study, we focused on inspecting these features on the ground.

After completion of our photo-mapping, we traveled to El Salvador in September 2001 to examine selected landslides in the field to determine their characteristics and to evaluate features whose origin was uncertain based on our interpretation of the aerial photographs. We examined many landslides from the air during helicopter overflights, particu- larly those in remote locations. On the ground, we also visited selected landslides near roads. Our field review immediately revealed how extensively the tropical vegetation had overgrown the landslide source areas and deposits in less than three years. We could confidently recognize the landslides that we had mapped on the aerial photographs, but in most cases, these landslides were covered by grasses and brush that were virtually the same as the vegetation on adjacent slopes. Based on our observations, nearly all of the shallow landslides in El Salvador caused by Hurricane Mitch will be fully overgrown and indistinguishable from nearby vegetated slopes in 3-5 years after the storm.

\section{General Characteristics of the Storm-Induced Landslides}

Tn comparison to the other three

Icountries where post-hurricane landslide studies are being conducted, the impact of landslides in El Salvador was modest and geographically limited. The abundant rainfall associated with the storm did cause dozens of landslides in various parts of the country, but overall, the impact of these landslides was far less serious than the human losses and damage caused by flooding in El Salvador. In parts of Honduras, Nicaragua, and Guatemala, landslides denuded almost entire slopes in some drainage basins (Harp and others, 2002; Bucknam and others, 2001, Cannon and others, 2001); in contrast, in El Salvador, the landslides were widely scattered, and although they did cause serious problems locally, they did not create a major national disaster.

Virtually all of the Hurricane Mitch landslides in El Salvador were shallow failures that involved the downslope movement of mainly unconsolidated surficial materials that are the product of deep tropical weathering. Most of the landslides moved downslope as generally coherent masses and stopped at the base of a steep slope, but many of these masses became internally fragmented by the time they stopped moving. In some cases, the sediment in these landslides contained enough water to become more fluid and evolve into debris flows. Debris flows can be very damaging and deadly because they travel rapidly and can flow down the relatively low-gradient slopes of streams and river valleys.

In addition to landslides caused by the hurricane, we also mapped a few large, pre-hurricane landslides. These include both complex landslides that have apparently been inactive for a long time and persistently active landslide complexes. Most of the inactive landslides have distinct, but rounded headscarps hummocky topography, and most appear to be earth slides and earth flows. Some involve large volumes of material and are deep-seated failures that include the unconsolidated surface soil and underlying bedrock. These pre-Mitch landslides include both translational and 
rotational landslides. The most prominent active, pre-hurricane landslide is the El Zompopera landslide near the Honduran border, a large retrogressive earth-slide debris-flow (avalanche?) complex (Plate 4).

We emphasize that our mapping does not provide a complete inventory of all landslides in our study areas. We concentrated our efforts on mapping the landslides cause by the hurricane (shown in red on the plates), but during our mapping, we also noted and mapped a few prominent landslides and landslide complexes that pre-date the hurricane (shown in green on the plates. On Plate 6, we also include a few features (shown in orange) that we describe as possible landslides, but we were not certain of their origin and were not able to examine them in the field.

\section{Aerial Photograph Observations and Interpretations}

$\mathrm{T}$

The features we interpreted as

Hurricane Mitch landslides have a fresh, generally unvegetated appearance on the post-hurricane aerial photography. Many features have evidence of a head scarp, which is where the landslide originated, a path or channel along which the slide moved, and a depositional zone in the lower parts of the slide where the debris accumulated. During our examination of the photographs, we noted lessdistinct features whose origin was less certain. We specifically concentrated our field review on these features. Several types of features visible on the photographs could be easily misinterpreted as recent landslides because they lacked vegetation or they appeared bright on the photography. In places, bright reflections

\section{Field Observations}

$\mathrm{O}$ ur reconnaissance field review in September 2001 confirmed our photographic interpretations and allowed us to examine selected features on the ground. We viewed many features from the air, particularly those in remote locations that would be difficult to access on the ground. We also visited selected features on the ground to better determine their origin or to get information on the size and characteristics of the landslides. Given the limited time for these field studies, the remoteness of many from grassy slopes oriented directly toward the sun mimicked the unvegetated slopes that characterized Mitch landslides. Although initially deceptive, we quickly became proficient at distinguishing between true landslides and these reflective grassy slopes. In other places, the rocky talus adjacent to rock outcrops had a bright appearance that could be confused with Mitch landslides. In a few cases, we had to examine these features in the field to determine if they were talus slopes or landslides. Lastly, the bright reflectance of a few man-made features, such as small quarries and hillside excavations, could be confused with fresh landslides and required field visits to verify their origin. landslides, and the difficulty of travelling overland through dense vegetation, we could only reach a few features on the ground. Our observations of most of the features on the ground were limited to viewing them with binoculars from distances of a few hundred meters. Although it would have been best to examine all of these features closely, it was impractical to do so, and we were forced to rely on more distant inspections. 
Many of the landslides mapped on the accompanying plates consist of small debris flows that were triggered by heavy rain from the hurricane that fell on already saturated ground. Many of these debris flows originated in the upper parts of small drainages that funnel into small gullies. It is noteworthy that many similar small gullies on the adjacent slopes were not activated during the storm even though the geomorphology of the adjacent gullies shows that debris flows had flowed down these gullies in the recent past. These relations indicate that abundant rainfall is not the only prerequisite to generate debris flows: a sufficient volume of unconsolidated material must be present in the catchment basin to slide during heavy rainfall events.

The 13 January 2001 and 13

February 2001 El Salvador earthquakes caused thousands of landslides throughout the country. These earthquakeinduced landslides left a strong imprint on the landscape and are summarized by Jibson and Crone (2001) and Baum and others (2001). Therefore, we do not discuss them at length in this report, but offer additional comments in the Summary Section of this report.

\section{Description of Selected Features in Specific Study Areas}

\section{The Santa Ana-Ahuachapan Study Area}

$\mathrm{T}$

The Santa-Ana-Ahuachapan study area in western El

Salvador (Figure 3) contains only a few concentrations of relatively small storminduced landslides (Plates 1 and 2). The central part of the area is characterized by steep volcanic terrain, whereas the northern and southern parts have more subdued topography related to the moderate to gently sloping flanks of the coalescing volcanoes of the rugged central volcanic terrain. Bedrock in this part of El Salvador is a mix of volcanic and volcaniclastic rocks of the upper Tertiary Balsamo Formation and the Quaternary San Salvador Formation (Weber and others, 1978). In general, the older Balsamo Formation is exposed along the distal flanks of the central volcanic terrain where it outcrops beneath the overlying San Salvador Formation. Most of the hurricane-induced landslides are in the eastern part of the steep volcanic terrain. Small concentrations of landslides are present in the western part of the volcanic terrain and in the deeply incised valleys along and near the Río Paz, which defines the El SalvadorGuatemalan border in the northwestern corner of the area.

\section{Area north of Apaneca}

Several small, scattered landslides occurred along the northern flanks of the volcanic chain north and northeast of Apaneca (Plate 1). These landslides are all small, shallow slope failures along ridge flanks, and none formed debris flows. They are in sparsely populated, remote areas and did not damage roads or threaten villages.

\section{Area near Río Paz}

Most of the storm-induced landslides near the Río Paz are west of the river in Guatemala (Plate 1); only one small shallow landslide was mapped east of the river in El Salvador. This slide is along the northern wall of the Río Guayapa Tacuba valley where it did not threaten roads or settlements. Two of the Guatemalan landslides are along the channel of the Río Paz and probably resulted from undercutting of the riverbank during the storm. The other scattered slides in Guatemala are small, shallow, slope failures with no associated debris flows. 


\section{Area west and southwest of Lago de Coatepeque}

The largest concentration of landslides in this area is directly west and southwest of Lago de Coatepeque (Plate $2)$. Most of these slope failures are west of the lake along and near the eastern flank of Volcán Santa Ana O Ilamatepec. All of these landslides appear to be shallow failures, and only a few formed debris-flow channels with visible deposits at their bases. A few of the landslides damaged local roads, but none of the slides apparently damaged homes or infrastructure. The landslide closest to a population center is shown on the west flank of Cerro Pacho, directly east of the village of San Juan Las Minas El Chorizo (not shown on 1:50,00-scale map). Both aerial photographs and field reconnaissance of this landslide suggest that it is a very shallow slope failure that produces modest deposits at the base of the slope during most significant storm events; it does not appear to pose a significant threat to the nearby village. Aerial reconnaissance of the region south and west of Lago de Coatepeque revealed numerous post-Hurricane Mitch landslides that were probably caused by the 13 January or 13 February earthquakes (Figure 4). earthquakes.

\section{South flank of Cerro El Ojo de Agua de la Virgen}

Two storm-induced landslides on the south flank of Cerro El Ojo de Agua de la Virgen (Plate 2) are shallow slope failures on the flanks of small valleys. The western slide damaged a road in a coffee plantation, and the eastern slide formed a debris flow that traveled about $300 \mathrm{~m}$ down the valley.

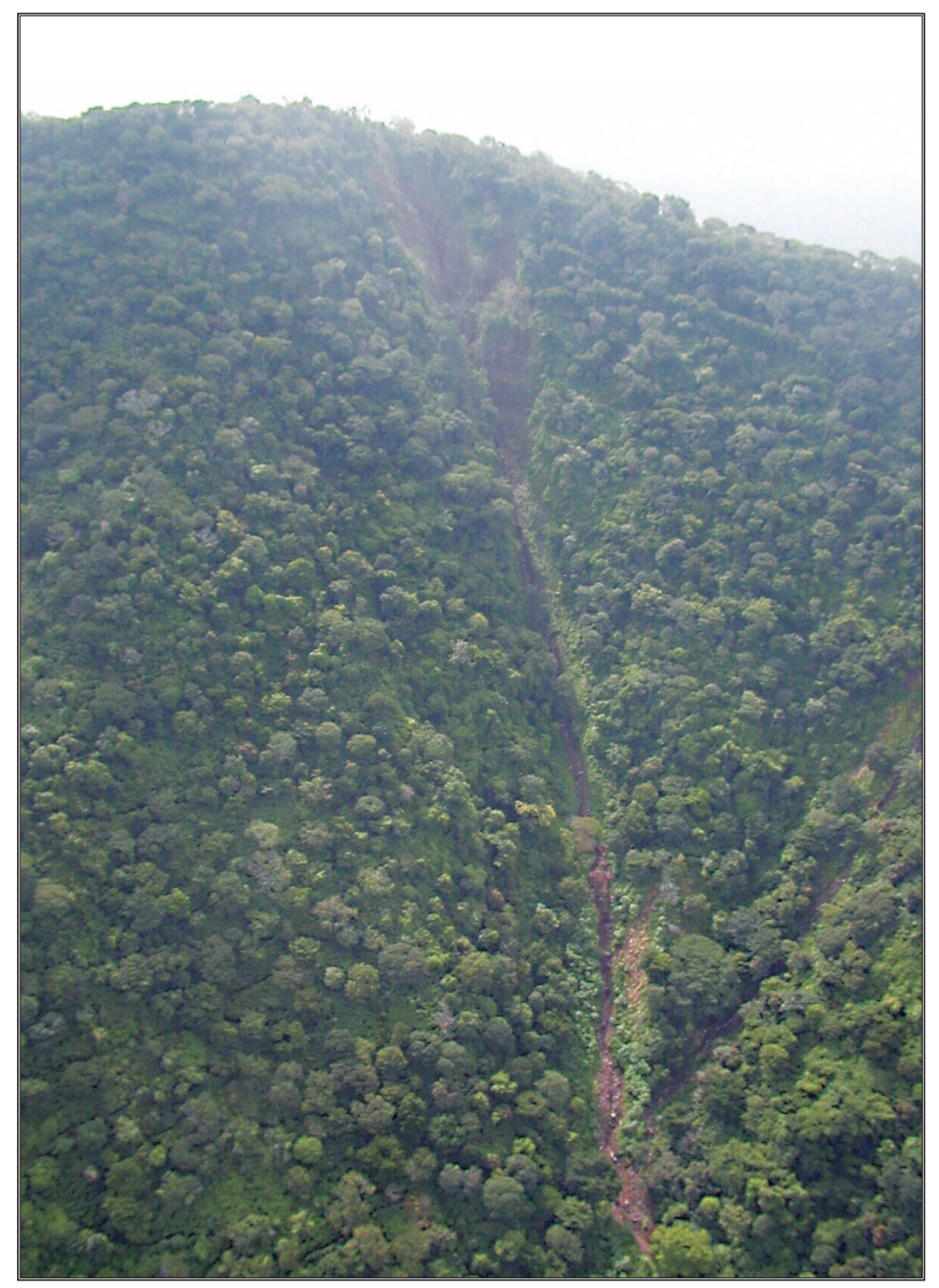

Figure 4. View of one of several recent landslides in the area south and west of Lago de Coatepeque. These recent landslides postdate January 1999 aerial photography and were probably triggered by the 13 January or 13 February 


\section{The San Ignacio-Tejutla Study Area}

$\mathrm{T}_{\mathrm{s}}^{\mathrm{h}}$ his study area in north-central El Salvador covers the mountainous part of the country near the Honduran border and contains the greatest concentration of storm-induced landslides that we mapped. The region is characterized by steep rugged terrain, deep canyons, and a variety of bedrock types. The bedrock in this part of El Salvador is composed of generally well-consolidated, Tertiary-age intrusive and extrusive rocks of the Chalatenango and Morazàn Formations (Weber and others, 1978).

\section{El Rosario Area}

Hurricane Mitch produced a significant concentration of landslides near the Honduran border east of the towns of El

Figure 5. View to the northeast of the upper part of El Zompopera landslide. The collapse of unstable blocks in the upper part of the landslide destroyed a road at the crest of the ridge. Many unstable blocks remain in the upper part of the slide and a catastrophic collapse of those blocks could potentially dam the Río La Palma at the bottom of the valley.
Rosario and San Ignacio (Plate 4) and about $10 \mathrm{~km}$ to the east, in Honduras on the north side of Río Sumpul. Near El Rosario, numerous landslides occurred in the upper part of Quebrada de La Mojarra and on the south flank of Loma La Albarda. Most of these landslides are several hundred meters long and added a substantial amount of fresh sediment to the adjacent drainage channels, but there are no significant settlements in the area so the risk posed by these features is minimal. A prominent debris flow that started on the southeast flank of Cerro Cayaguanca flowed about $1 \mathrm{~km}$ down the lower channel of Quebrada de La Mojarra. The debris flow remained in the channel and stopped several hundred

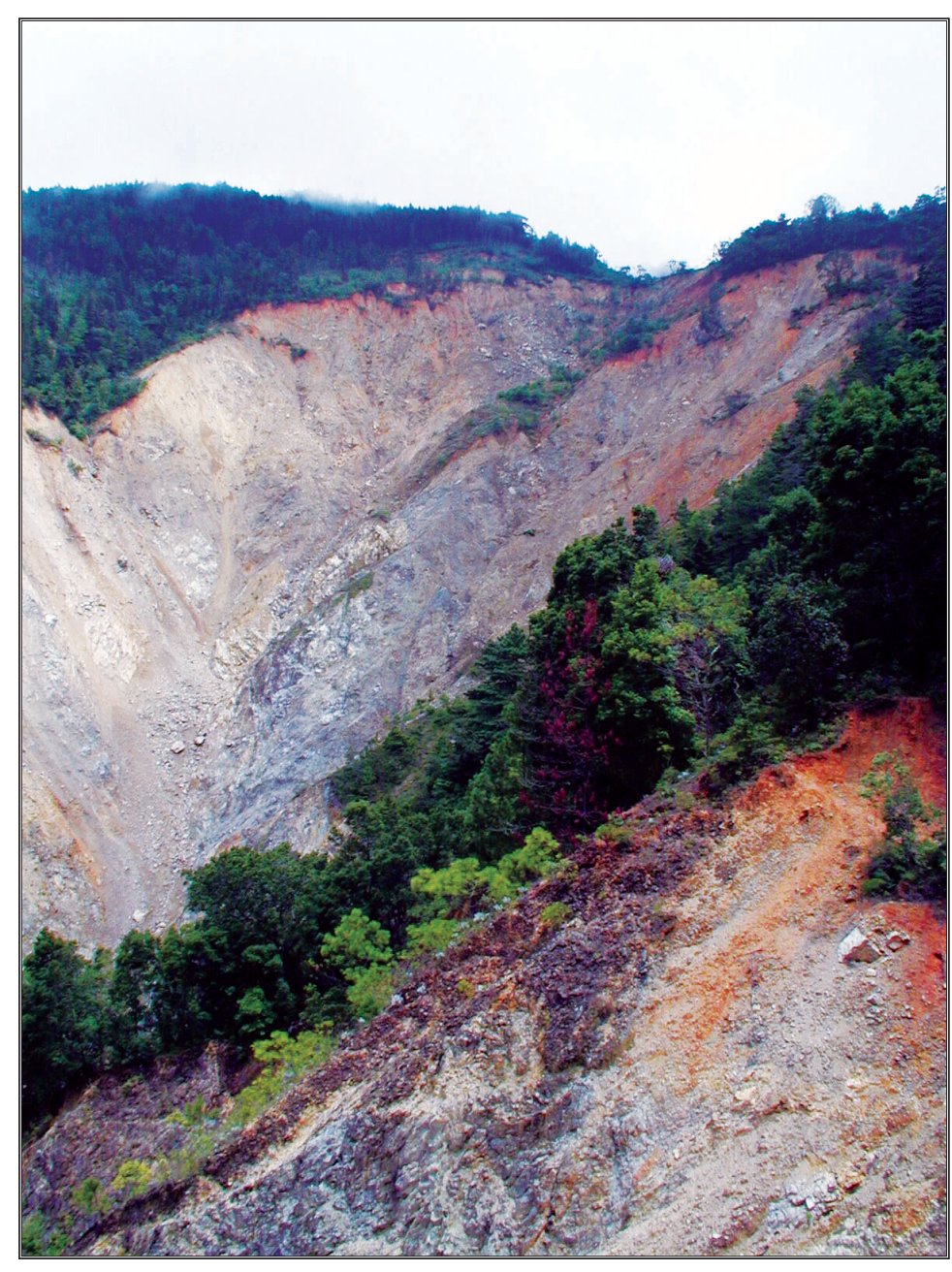
meters above the town of El Rosario. Debris flows of similar or slightly larger size probably do not pose a direct hazard to the town because the main channel is incised several meters deep into the alluvial fan on which the town is built.

\section{El Zompopera Landslide}

El Zompopera landslide is the largest single landslide that we mapped in all of our study areas. The head of the landslide is about $300 \mathrm{~m}$ above the adjacent valley, and the denuded slopes drop steeply into the valley (Figure 5; Plate 4). Bedrock exposed by the land- 
Figure 6. View of the El Pinar landslide and the abandoned school. A new road has been graded across the head of the landslide, which slid into the valley of the Río La Palma o Las Pozos on the right. Future movements on the landslide will likely disrupt the new road.

slide has been extensively altered to clay, which suggests that this alteration may be a factor that contributed to the location of the landslide.

Although El Zompopera landslide was active prior to the hurricane, the storm caused unstable blocks in the upper part of the landslide to fail and add huge amounts of sediment to the adjacent valley of the Río La Palma o Los Pozos. This sediment initially moved into the valley as an earth slide and debris flow but, farther downstream, the landslide deposits were partially reworked into flu-

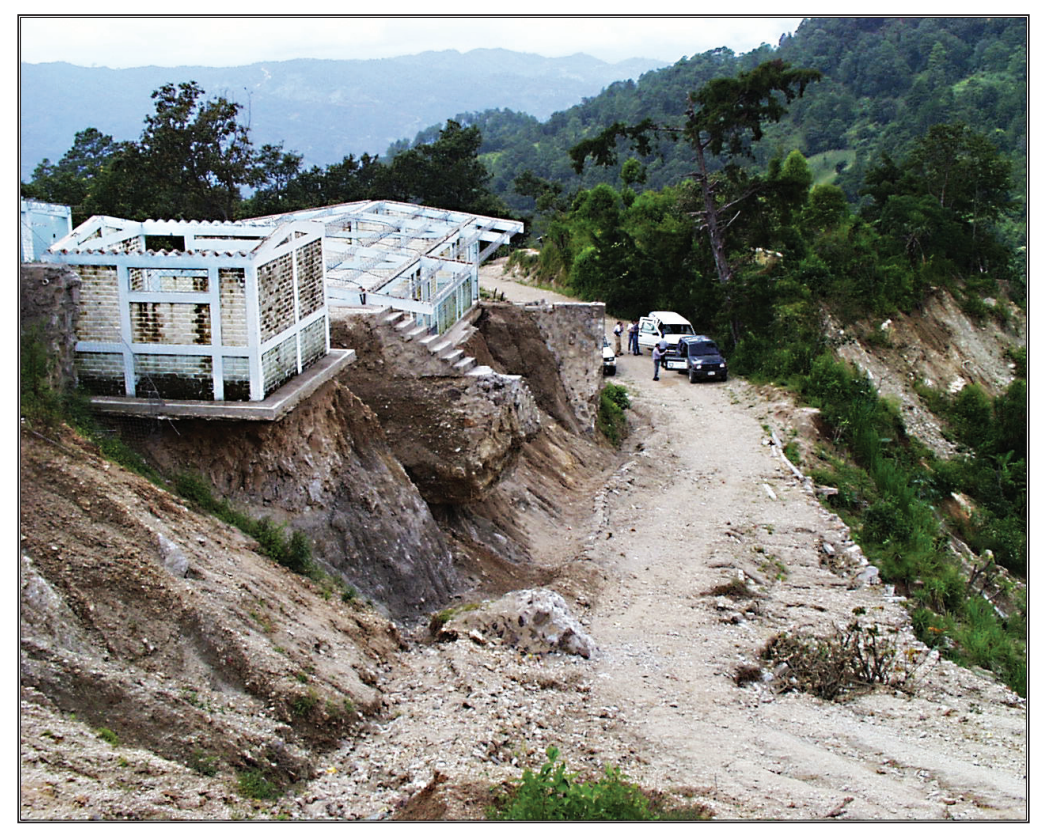

part of the town. Fortunately, the town is located about 5-10 $\mathrm{m}$ above the river channel, but a large catastrophic flood could threaten parts of the town.

\section{El Pinar Slide}

Approximately $2.5 \mathrm{~km}$ downvalley from the $\mathrm{El}$ Zompopera landslide, a large earth slide near the settlement of El Pinar destroyed about 50

vial deposits. Fresh deposits of this mixture of fluvial and landslide sediment extend 6-7 km downvalley, beyond the town of La Palma and the bridge of Highway CA-4. At the highway bridge, which is about $6 \mathrm{~km}$ from the landslide, these deposits contain boulders that are more than $2 \mathrm{~m}$ in diameter.

The storm also caused significant retreat of the scarp at the head of the landslide, which destroyed a road that provided access to the surrounding countryside. The road has been temporarily reopened, but unstable blocks in the upper part of the slide will continue to collapse and eventually destroy the temporary road. $\mathrm{m}$ of road and the only school in the area (Figure 6; Plate 4). El Pinar is located about $3 \mathrm{~km}$ east-northeast of La Palma, on the 15- to 25 -m-wide crest of a steepsided ridge. The landslide began at the crest of the ridge and traveled downslope about 150-200 m to the bottom of the Río La Palma o Los Pozos valley. The landslide undermined the foundation of the local school, which was not occupied when the failure occurred. A new road has been graded across the head of the landslide, but the slope of the landslide remains unstable and future movements will likely disrupt the road again and could threaten nearby homes. 


\section{Cerro El Coyote Debris Flows}

Hurricane Mitch generated two debris flows on the south side of Cerro $\mathrm{El}$ Coyote, which is about $5.5 \mathrm{~km}$ northnortheast of El Paraiso and $3.5 \mathrm{~km}$ northwest of San Rafael (Plate 5). These debris flows had estimated volumes of a few thousand cubic meters, originated on steep, tree-covered slopes, and flowed 300-400 m down narrow channels. Levees along the western debris flow show that the flow filled the 5-m-wide channel to a depth of 3-4 m and transported 2-m-wide blocks more than half way down the channel (Figure 7). The source areas of the debris flows are now completely overgrown, and even much of the coarse bouldery deposits is concealed by heavy vegetation. The catchment basins where the debris flows originated are very small relative to the volume of rock and water involved in the flow. During our field review, we observed several small flowing springs on the lower slopes of the Cerro El Coyote. We speculate that groundwater from springs scattered around Cerro El Coyote may have added to the surface runoff from the hurricane and may have been a factor in the development of these small, but highly fluid and powerful debris flows.

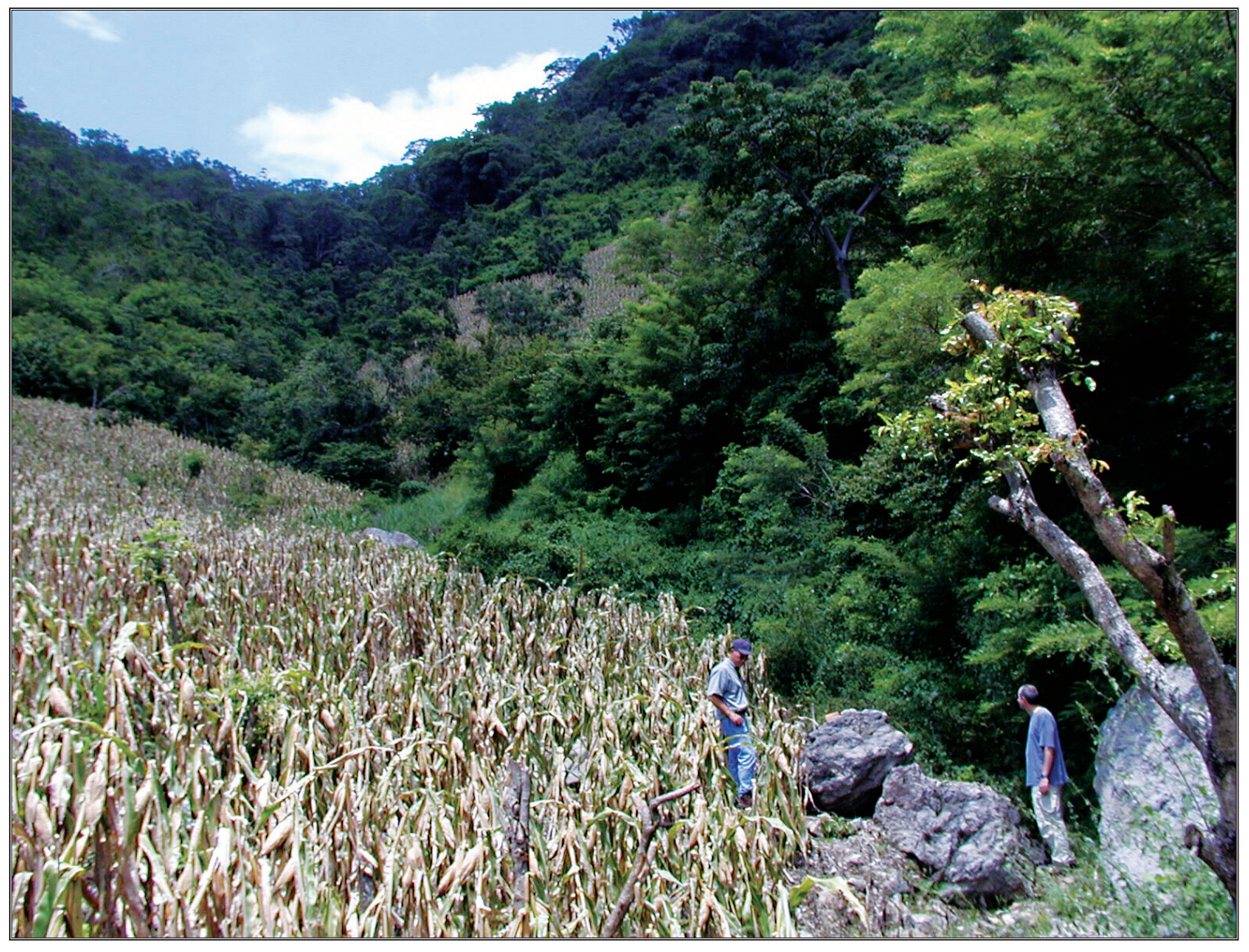

Figure 7. View of the western debris-flow channel and source area on Cerro El Coyote. The source area of the flow is at the ridge in the upper left of the photograph. Person on the left is standing on the debris-flow levee, which is about 3-4 $m$ above the channel bottom. Note the 2-m-wide boulder (lower right) that was carried by this small but powerful debris flow. 


\section{San Miguel—Berlin Study Area}

\section{Volcán de San Vicente}

We are unaware of any landslides on Volcán de San Vicente that were specifically triggered by Hurricane Mitch, however, several other recent geologic events have produced landslides on the volcano. A group of pre-Mitch debris flows on the south side of Volcán de San Vicente (Plate 8) are visible on the November 1999 JICA photography and were triggered by an earlier strong storm (Jon
Major, USGS, oral commun., 2001). Most of these flows are at least $1 \mathrm{~km}$ long, and the longest is about $3 \mathrm{~km}$. The M 6.5, 13 February 2001, El Salvador earthquake triggered several landslides on the volcano (Baum and others, 2001), and a storm on 15 September 2001 caused additional landslides and debris flows. A debris flow from the 15 September storm swept through the northeastern edge

Figure 8. View of part of the town of Guadelupe that was struck by a debris flow on 15 September 2001. Temporary shelters in the right foreground were swept away by the debris flow, which originated on the western slopes of Volcán de San Vicente, shown in the background.

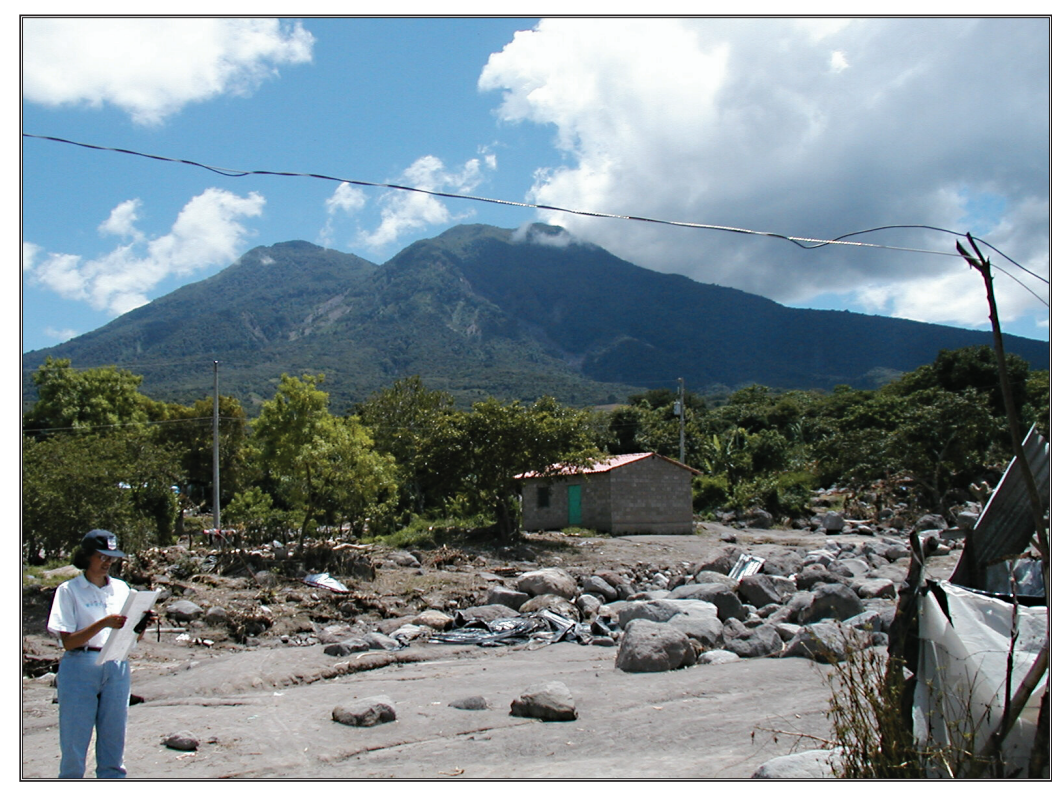
of the town of Guadelupe, destroyed several temporary shelters, and carried away a woman and a small child (Figures 8, 9, and 10). Other debris flows that swept across the highway between Guadelupe and Verapaz traveled several kilometers from their source areas on the east side of the volcano.

Figure 9. Oblique aerial view of the main source area for the debris flow that occurred on 15 September 2001 on Volcán de San Vicente. Smaller landslides along the banks of the channel, farther downslope also contributed sediment to the devasting debris flow that swept through Guadelupe.

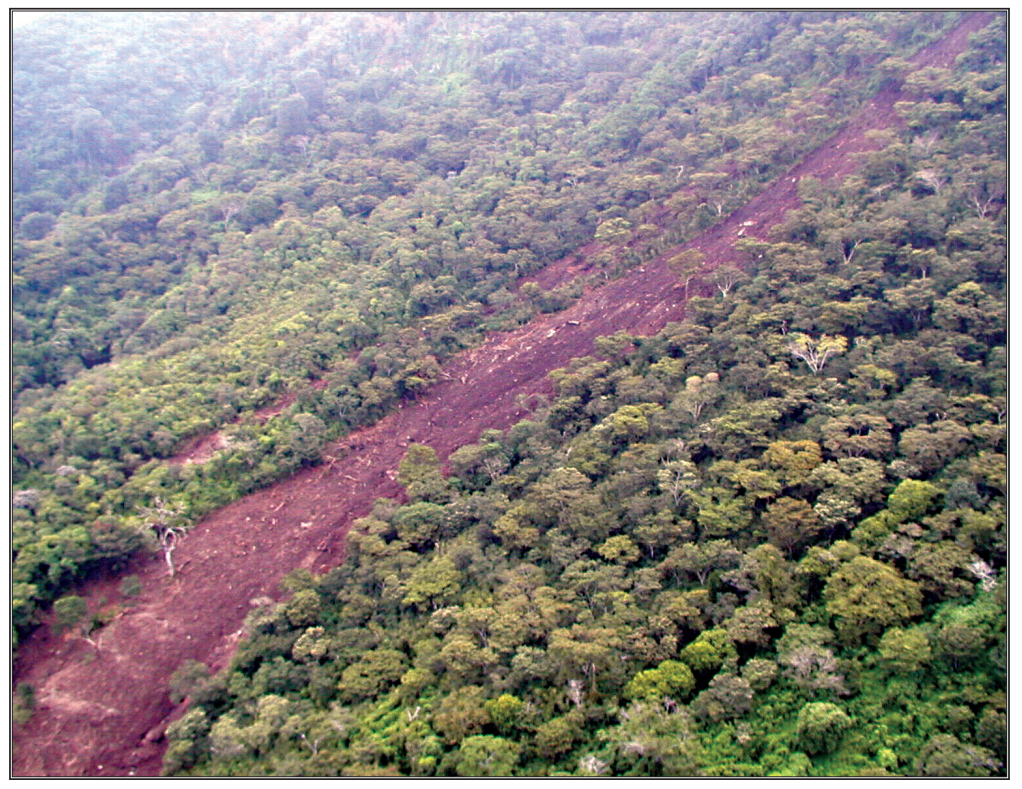




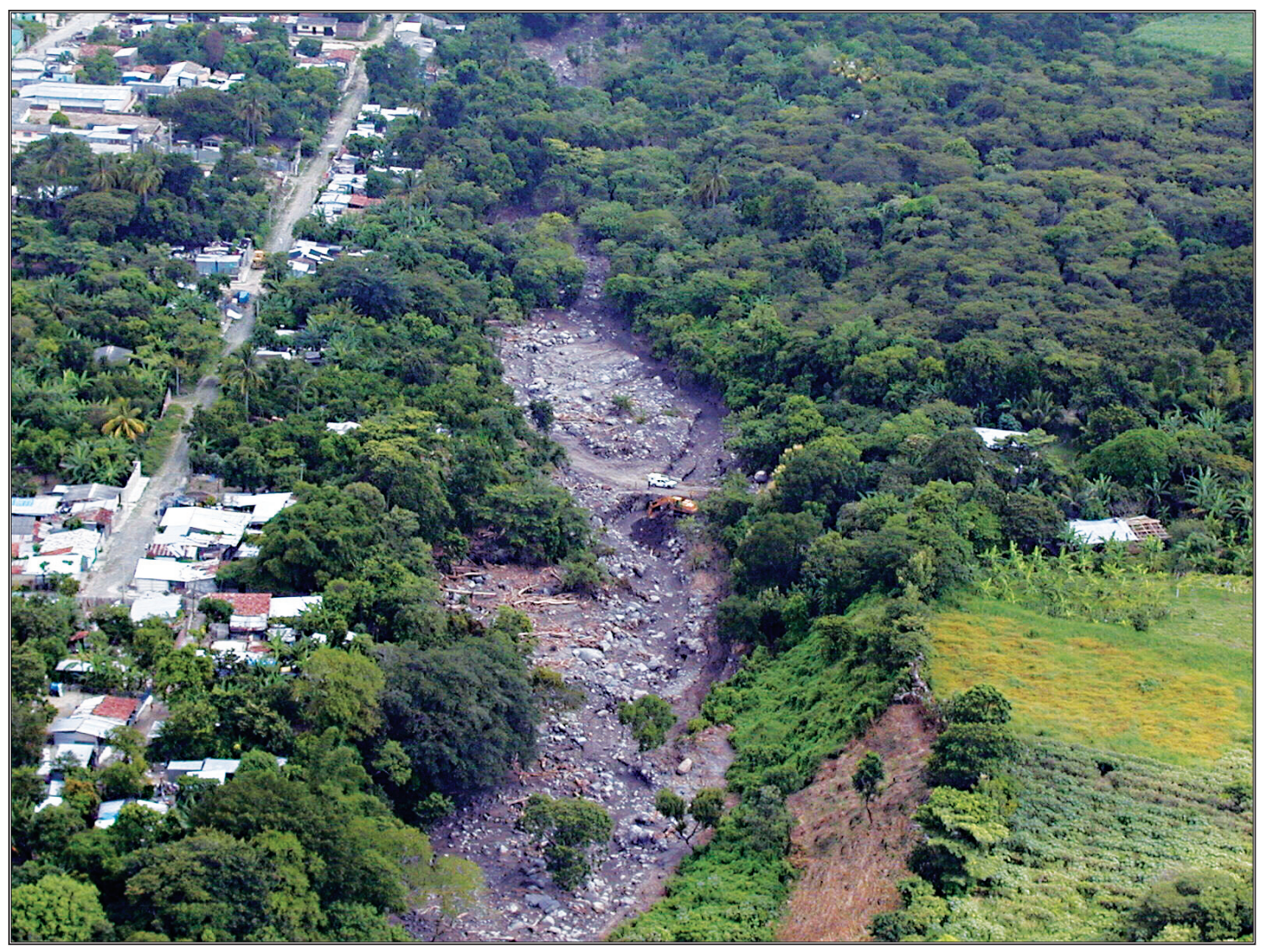

Figure 10. Oblique aerial view of the debris flow on the northeast side of the town of Guadelupe that occurred on 15 September 2001. Many of the large boulders in the channel were transported by the debris flow.

\section{Canyons southwest of San Lorenzo}

Perhaps the largest concentration of hurricane-induced landslides in the eastern part of El Salvador occurred on the canyon walls southwest of San Lorenzo (Plate 8). These slides are dominantly shallow failures of what appears to be weathered tephra (Figure 11). The slides range in length from several tens of meters to about $200 \mathrm{~m}$, and most reached the canyon bottoms where they deposited sediment in the channels of intermittent streams. Similar slides occurred in the area as a result of the 13 February 2001 earthquake (Figure 12). These slides continue to pose a minor hazard to homes and roads at the top of the slopes as their headscarps continue to retreat. Fortunately, few homes appear to be built on the canyon walls or bottoms, where significant landslide hazard exists.

\section{Berlin and Santiago de Maria area}

Landslides near the towns of Berlin and Santiago de Maria occurred on the four volcanoes in the area (Plate 10). Although most were far from settlements, a few slides disturbed roads, and one came within $100 \mathrm{~m}$ of a small settlement

\section{Cerro El Tigre}

Several debris flows occurred in canyons on the south and southeast sides of Cerro El Tigre (Plate 10). Individual flows ranged in length from about 100 to $500 \mathrm{~m}$. Most originated on the walls of canyons or at the heads of tributary channels, and many reached the canyon floors where they entered main channels and coalesced with other flows. Those that entered the main channels flowed hundreds of meters downslope, creating 


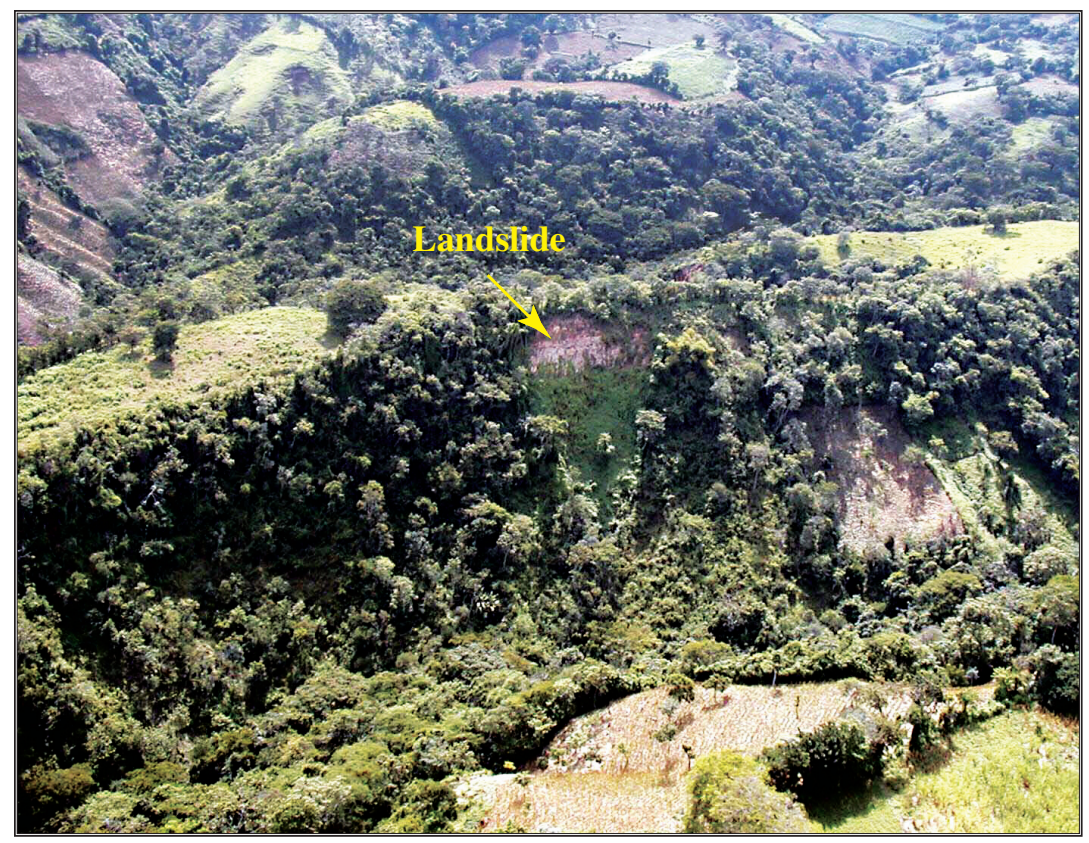

Figure 11. Partially overgrown scar of a shallow landslide in the area west of San Lorenzo. Dozens of small shallow landslides similar to this one occurred in this area as a result of Hurricane Mitch, but few caused significant damage.

composite debris flows as much as $900 \mathrm{~m}$ long. Although the slopes in this area are sparsely settled, homes and farms near the mouths of major canyons could be threatened by debris flows in future storms. The 13 February 2001 earthquake also caused landslides in this area.

\section{Volcán de Usulután}

Debris flows occurred on the northeast quadrant of Volcán de Usulután, and in the deep, rugged canyons on the east and west sides of the volcano (Plate 10). The flows are about 100 $\mathrm{m}$ to $800 \mathrm{~m}$ long and formed on both steep and moderate slopes. In addition to the flows shown on the maps, several others occurred in the rugged canyon east of the summit and are visible on a single vertical aerial photograph (Figure 13). However, we do not have stereographic coverage of this area, and could not accurately map these landslides. The 13 February 2001 earthquake also trig-

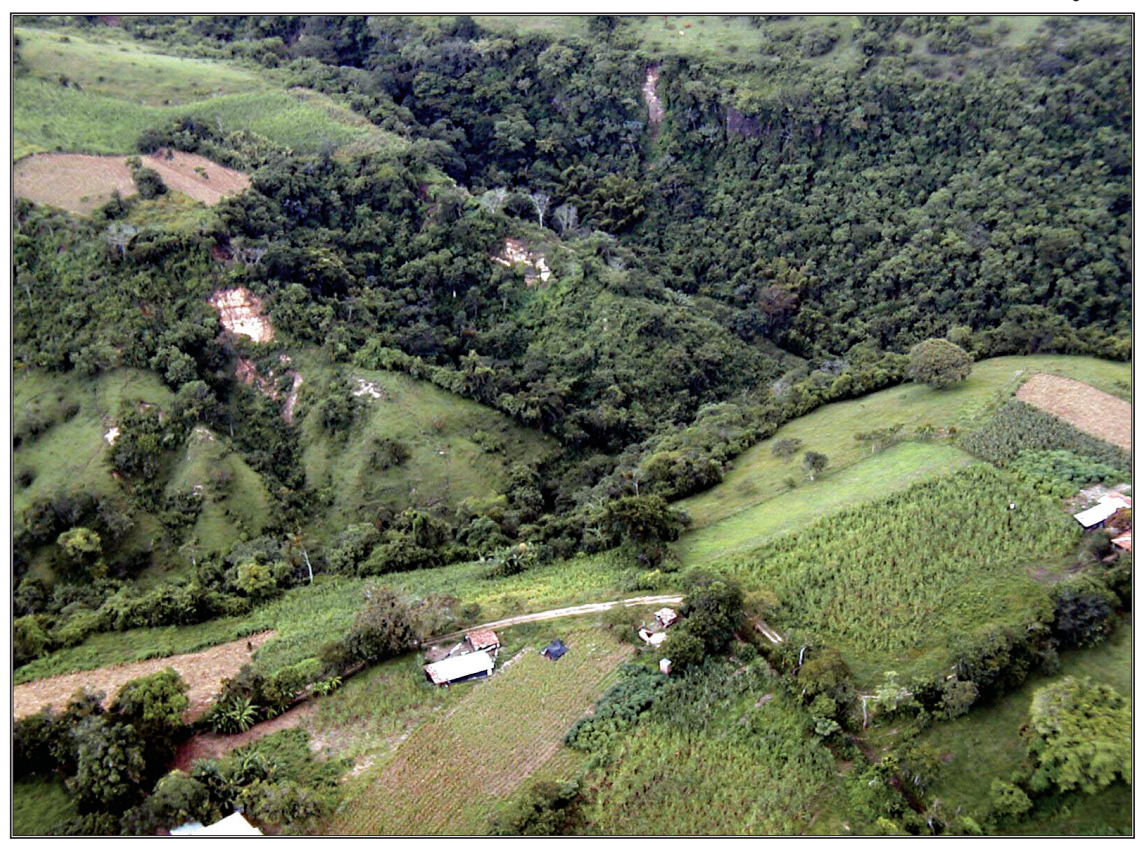

Figure 12. Scars of landslides caused by the 13 February 2001 earthquake west of San Lorenzo. Like the Hurricane Mitch landslides, these shallow landslides caused little serious damage, but repeated sliding here shows that these slopes are highly susceptible to landslides. gered numerous landslides on the volcano (Figure 14). The volcano's high relief (about $1000 \mathrm{~m}$ ) and steep slopes create the potential for longrunout debris flows, similar to those that occurred on Volcán de San Vicente.

Laguna de Alegria and Cerro Las Palmas

Several slides and debris flows occurred inside the crater rim of Laguna de Alegria and on steep slopes to the southwest, below Cerro Pelon and Cerro Las Palmas (Plate 10). Most originated mainly as shallow land- 
Figure 13. Part of vertical aerial photograph (USGS R2 L2 F1) showing recent debris flows (see arrows) on Volcán de Usulután. These slides were not mapped due to incomplete photographic coverage near the summit of the volcano.

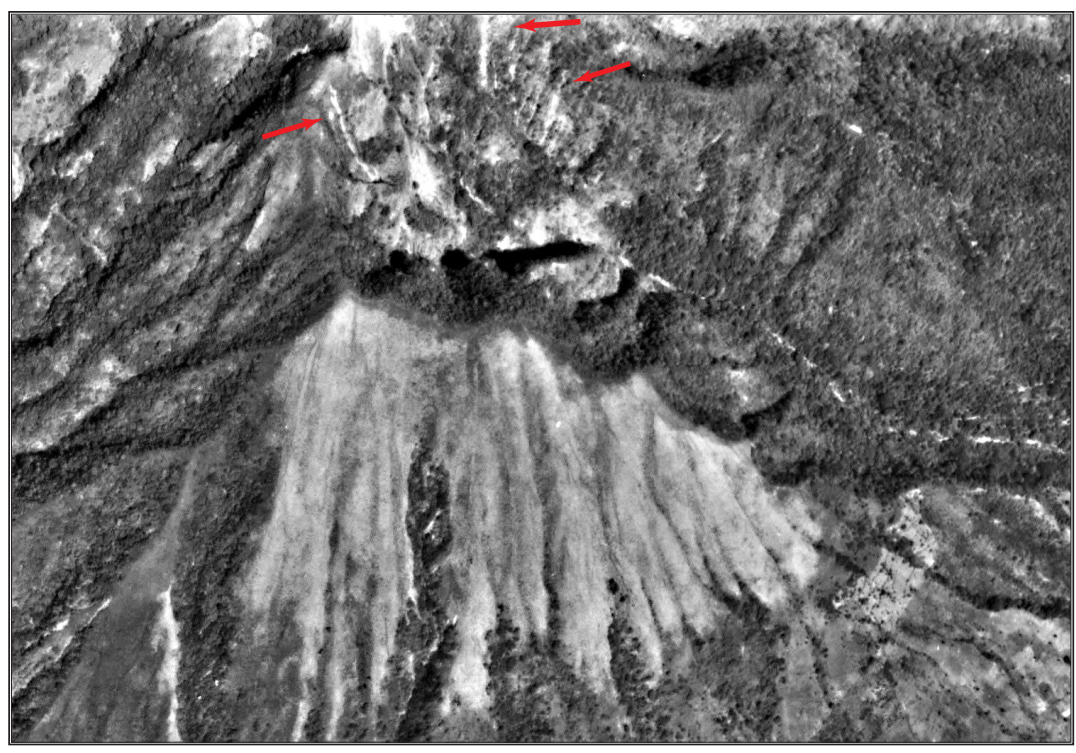

Figure 14. Scars
of landslides on
Volcán de
Usulután triggered
by the 13 February
2001 earthquake.
Numerous land-
slides like these
occurred on the
volcano as a result
of strong shaking,
and produced
large amounts of
sediment that will
be eroded from the
volcano and
deposited in sur-
rounding areas
during future
years.

slides in colluvium and weathered residuum derived from the volcanic rock. The slides and flows range in length between about 200 to $1500 \mathrm{~m}$. The longest flow entered an unnamed intermittent stream that flows along the eastern edge of the town of Tecapan and stopped about $2 \mathrm{~km}$ north of the town. The path of the flow was within $100 \mathrm{~m}$ of a few homes on the slopes below Loma El Pinal. The 13 February 2001 earthquake triggered several landslides in this general area.

\section{Cerro El Taburete}

Two landslides that occurred inside the crater rim of Cerro El Taburete appear to be shallow landslides in colluvium and weathered residuum derived from the volcanic rock (Plate 10). The larger of these slides is about $200 \mathrm{~m}$ long and started at the crater rim; the second is about $80 \mathrm{~m}$ long and initiated about midway up the crater wall. In the field, we observed new landslides inside the crater rim and on the outside of the volcano that were triggered by the 13 February 2001 earthquake (Figure 15). 


Figure 15.
Landslides inside
the crater of Cerro
El Taburete that
were probably
caused by the 13
February 2001
earthquake. Many
similar landslides
occurred on this
and nearby volca-
noes as a result of
the earthquake.
Shallow landslides
in this area that
were caused by
Hurricane Mitch
were probably
very similar.

Figure 15.

the crater of Cerro

El Taburete that

were probably

caused by the 13

February 2001

earthquake. Many

similar landslides

occurred on this

and nearby volca-

the earthquake.

Shallow landslides

in this area that

were caused by

Hurricane Mitch

very similar.

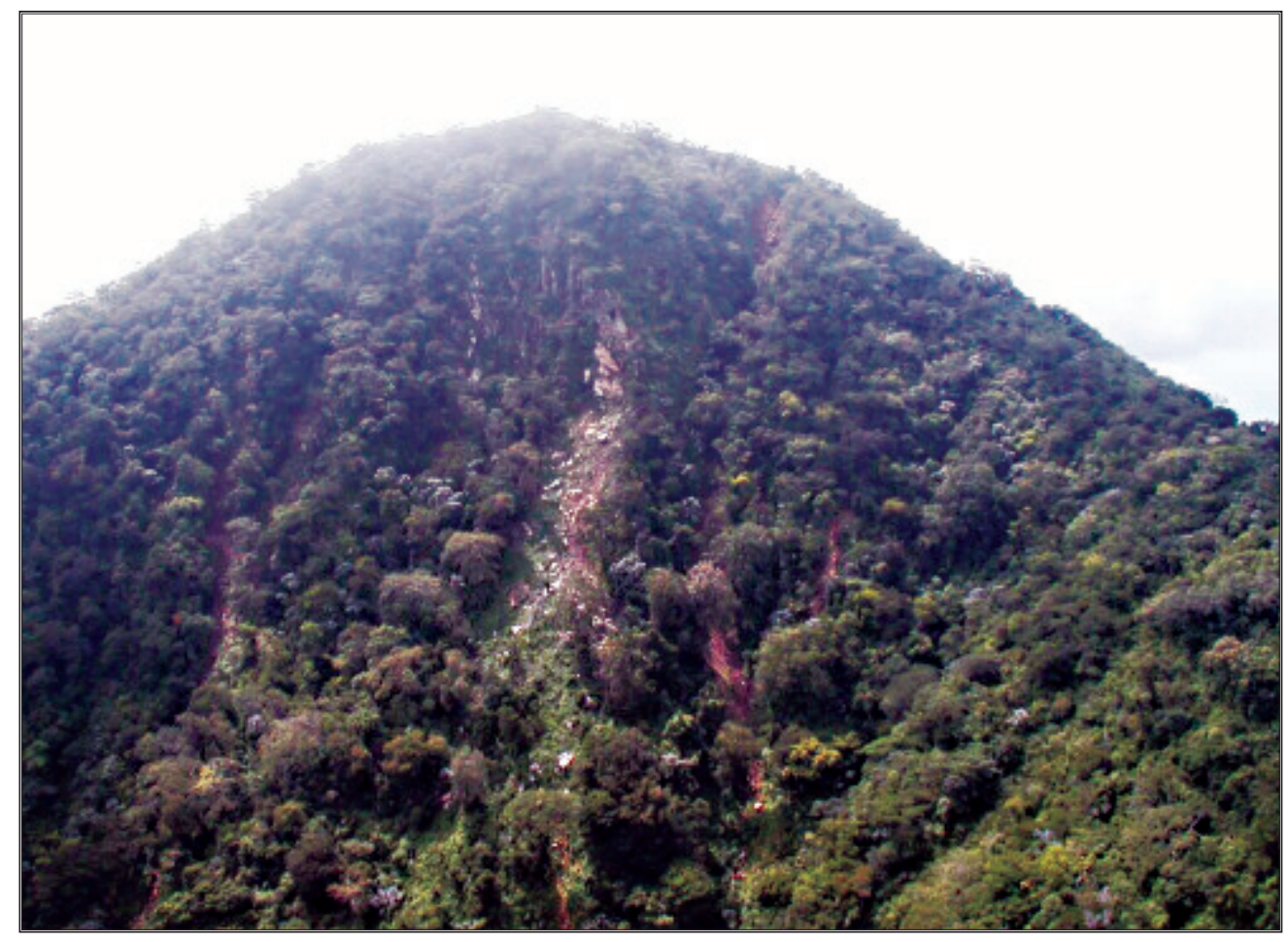

\section{San Miguel area}

Small groups of debris flows or other shallow landslides occurred in isolated areas surrounding the city of San Miguel (not shown on plates), but few of these slides pose any threat to settlements or manmade structures.

\section{Laguna Seca El Pacayal}

A few debris flows occurred inside the west rim of the crater Laguna Seca El Pacayal, west of San Miguel (Plate 10). The flows started just below the rim and extend 400-500 m east to the edge of the crater floor. The only manmade structures inside the crater are on the opposite (east) side and were not threatened by the debris flows.

\section{Hills east of San Francisco (Gotera)}

A few isolated debris flows occurred in the sparsely settled hills east of San Francisco (Gotera), north of San Miguel (Plate 11a). The flows range in length from about $50 \mathrm{~m}$ to $300 \mathrm{~m}$, and some cross trails, but are several hundred meters from any homes or major roads.
Hills south of Laguna de San Juan A few small debris flows that occurred in the hills south of Laguna de San Juan were in relatively rugged, sparsely settled terrain (Plate 11b). The largest flow was about $200 \mathrm{~m}$ long and about $1 \mathrm{~km}$ from the nearest settlement, but others occurred within 300-400 m of a small settlement at the confluence of Quebrada El Naciemiento and Quebrada La Cangrejera.

\section{El Carmen}

A few debris flows occurred in the hills north and northeast of El Carmen (Plate 11c). These include a small isolated flow near the top of Loma Los Torres and several small flows on Loma La Ujushtera. The debris flows range in length from a few tens of meters to almost $200 \mathrm{~m}$ and were too far from settlements to pose a hazard. However, if an intense storm triggered large debris flows, then a few houses in the bottom of Quebrada El Agua Helada could be at risk. 


\section{Embalse 15 de Septiembre}

The hydroelectric dam that impounds the Río Lempa to form the Embalse 15 de Septiembre is a major source of elec- tricity for El Salvador. Concern for the safety of El Salvador's hydroelectric dams and associated infrastructure is a major reason for investigating slope stability around the reservoir. We found relatively few slides near the Embalse 15 de Septiembre, and none pose serious threats to the dam (Plate 9). A few slides occurred on the shoreline and others occurred on the banks of two major tributaries of the Río Lempa.

\section{Shore line}

The few landslides observed along the shores of the Embalse 15 de Septiembre are unlikely to pose any serious threat to the dam or reservoir. These slides include a debris flow on the southwest shore (about $400 \mathrm{~m}$ upstream from the dam), a large prehurricane rotational slide on the northwest shore (Figure 16, $5 \mathrm{~km}$ upstream from the dam), and a shallow landslide on the west wall of the flooded Río Malancolo valley (Figure 17, $7 \mathrm{~km}$ upstream from the dam). Of these, only the pre-hurricane slide has a large enough volume to have a significant impact on the reservoir. We

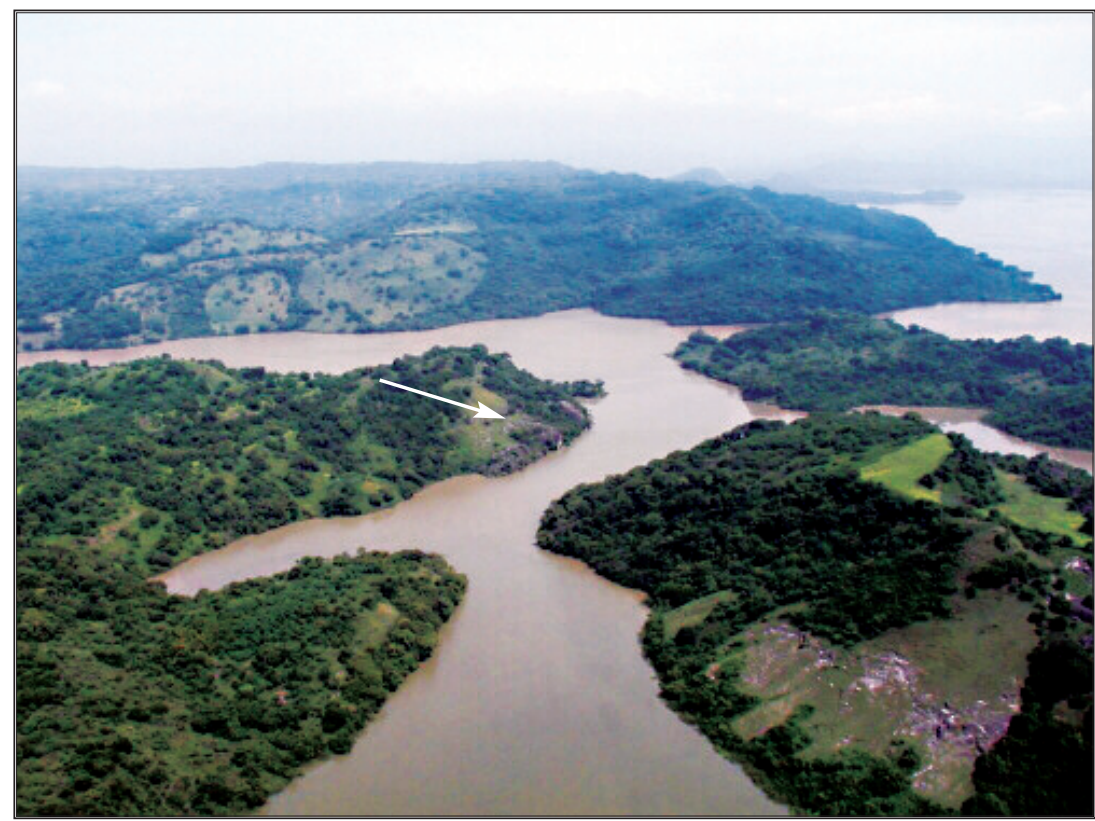
observed no signs of recent activity of the slide during an overflight in September 2001 (Figure 16). Reactivation of the slide might partially block the reservoir, but such a blockage is unlikely to be large enough to interfere with operation of the dam. 


\section{Bank failures on Río Titihuapa}

Banks of the deeply incised Río

Titihuapa are actively failing at a few places upstream from where the river enters the reservoir (Plate 9). Most bank failures are on the outside of meanders where undercutting has caused failure either by toppling or slumping. Bank failure at these locations likely was ongoing before Hurricane Mitch, but many of the scars or deposits look fresh on the air photographs. High flow in the Río Titihuapa during the hurricane may have accelerated these bank failures.

\section{Bank failures on Río Gualcho}

Banks of the deeply incised Río Gualcho are actively failing at several places downstream from Communidad Nuevo Gualcho, about $4 \mathrm{~km}$ upstream from where the river enters the reservoir (Plate 9). Most of the bank failures are on the outside of meanders where undercutting has caused failure either by toppling or slumping (Figure 18). Bank failure at these locations likely was ongoing before Hurricane Mitch, but many scars or deposits are fairly recent. High flow in the Río Gualcho from Hurricane Mitch may have accelerated these bank failures.

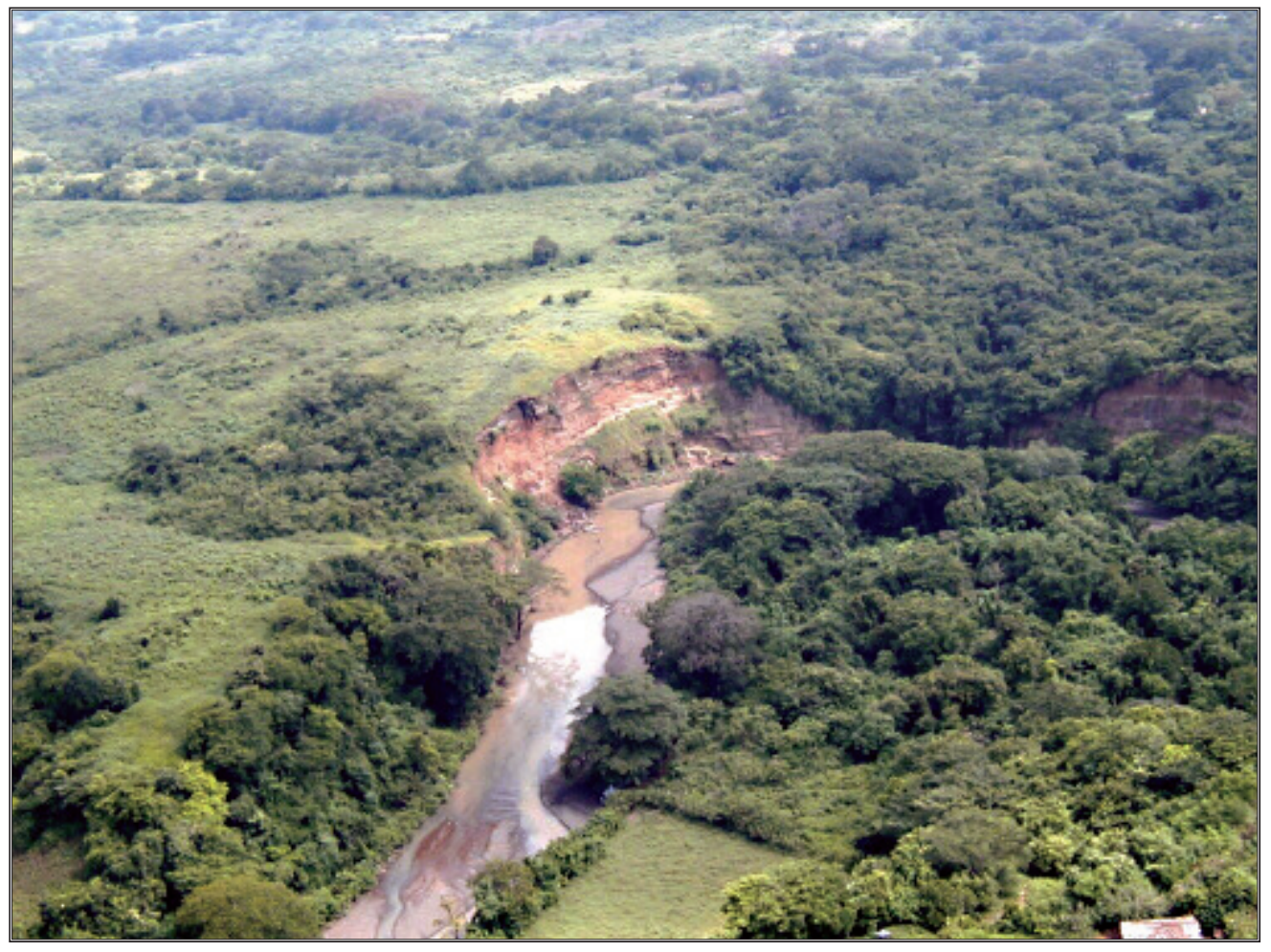

Figure 18. Bank failure on the Río Gualcho about $4 \mathrm{~km}$ upstream of Embalse $15 \mathrm{de}$ Septiembre. This and similar failures along the Río Gualcho may have resulted from accelerated bank erosion cause by the high stream flows that occurred during Hurricane Mitch. 


\section{Summary of Hurricane Mitch Landslides and Overview of Landslide Hazards in El Salvador}

$\mathrm{H}$ urricane Mitch was an unusually strong storm, but the most intense and abundant rainfall did not occur in El Salvador. Even though antecedent moisture in much of $\mathrm{El}$ Salvador was high, the storm caused relatively few damaging landslides. The high intensity and large amounts of rain that fell in areas of Honduras, Nicaragua, and Guatemala during the hurricane caused large and catastrophic landslides in those countries. Had similar intensities and amounts occurred in El Salvador, the extent and magnitude of landsliding would likely have been similar to those neighboring countries. More recent, strong localized storms have triggered landslides in El Salvador, such as those noted on the south and east sides of Volcàn de San Vicente.

Our mapping and field observations indicate that the steep slopes of volcanoes and other mountainous areas in the country are susceptible to landslides, particularly in areas where the bedrock is highly fractured or deeply weathered. Landslide masses moving down steep slopes commonly transform into rapidly moving debris flows and may travel hundreds or thousands of meters before stopping on gently sloping ground. Channel areas downstream and downslope of steep slopes are areas of potential inundation by debris flows and should be carefully evaluated prior to siting homes, businesses, or infrastructure. In our mapping, we also observed a few pre-hurricane landslide complexes, few of which were reactivated by Hurricane Mitch. However, disturbances such as grading or excavations on these landslides or changes in the surface drainage on them could reactivate these features.

Our general observations about some of the controls on these landslides can be tested by further analysis. This landslide inventory can be used as the first step in developing a more comprehensive analysis of landslide hazards. For example, GIS-based analysis of the distribution of landslides in relation to different geologic units would be useful to determine if specific types of bedrock are more susceptible to landsliding. This kind of susceptibility information can then be combined with a GIS-analysis of slope angles determined from digital elevation models. The merger of slope-angle information and the failure susceptibility of various rock types and surficial materials provides the basis for landslide susceptibility maps. With additional geotechnical data and the application of slope failure models, it would be possible to estimate landslide-travel distances and develop maps of potential debris-flow inundation zones. Such maps would be valuable tools to help identify areas where future development should be restricted or avoided, and should be developed to help mitigate landslide hazards in parts of the country where urbanization is occurring.

Although Hurricane Mitch caused damage and death in El Salvador, the earthquakes in 2001 demonstrated that the people of El Salvador are exposed to a variety of geological hazards. El Salvador is a geologically active country and large parts of the country consist of steep, rugged terrain. Intense rainfall events can obviously cause landslides, but the devastating earthquakes of 13 January and 13 February 2001 show that strong ground shaking can be a major factor in destabilizing slopes. Steep slopes and poorly consolidated volcanic deposits combined with strong ground shaking create conditions that are optimum for the development of extensive 
and massive landslides and ground failures (Jibson and Crone, 2001; Baum and others, 2001). Notably, earthquakeinduced landslides occurred in many of the same areas, although not necessarily in the exact locations, as storm-induced landslides. Areas subject to earthquakeinduced landslides, as well as storminduced landslides, include several volcanic areas, notably Lago de Coatepeque, Volcàn de San Vicente, and the volcanoes near Berlin and Santiago de Maria. Both earthquake- and storm-induced landslides also occurred in the area southwest of San Lorenzo.

The January and February earthquakes caused hundreds of landslides in the Balsamo Ridge area, which is located south and southwest of the city of San Salvador (Jibson and Crone, 2001). Although we have limited post-hurricane and pre-earthquake photography of this

\section{Conclusions}

The people of El Salvador live in an extremely active geological setting and are exposed to multiple types of geological hazards. Destructive landslides, floods, hurricanes, earthquakes, and volcanic eruptions are natural events that cannot be prevented. They have occurred in the past, and similar events will certainly occur in the future. With adequate planning and advance preparation, the detrimental effects of these destructive events can be minimized, and the scale of future disasters can be moderated.

Considering the billions of dollars in losses that occurred in El Salvador since 1998, steps to reduce future losses are cost-effective investments. The development of landslide susceptibility maps, area, this photography shows that the hurricane did not cause any notable landslides along the ridge. The estimated 300-500 mm of rain that fell on Balsamo Ridge during the hurricane (Figure 2) failed to cause any significant landsliding, whereas the brief but powerful shaking from the January and February earthquakes caused hundreds of landslides. These observations indicate that steep slopes, even those in poorly consolidated volcanic deposits, can remain stable during heavy rainfall, particularly if they are covered by heavy vegetation. However, those same slopes can fail catastrophically when shaken by strong earthquakes, even when they are dry. Thus, the dynamic strain related to earthquake shaking can cause widespread failure in slopes that are stable under static conditions. flood and debris-flow inundation maps, and seismic and volcanic hazard maps will provide public officials with valuable tools to guide future development and to help identify areas where existing development is exposed to natural hazards. Hurricane Mitch and the two devastating earthquakes have created a new awareness in El Salvador of the need to prepare in advance rather than respond after a disaster occurs. Scientific information such as the inventory contained in this report can be useful in planning for future hazardous events. Adequate planning and preparation can save the lives of Salvadorans and minimize the hardships that result from destructive natural events such as Hurricane Mitch and strong earthquakes. 


\section{Acknowledgments}

The successful completion of this project and its products relied on the cooperation and assistance of many people. We wish to especially thank Ana Elizabeth Araniva de Gonzalez, Office of Water and Environment, U.S. Agency of International Development, San Salvador, and Carlos Pullinger, Direccion de Geologia, Servicio Nacional de Estudios Territoriales (SNET), San Salvador for their continuous support, assistance, and cooperation throughout all phases of this work. Their assistance was invaluable. We also thank Manual Diaz (SNET) and

\section{References Cited}

Baum, R.L., Crone, A.J., Escobar, D., Harp, E.L., Major, J.J., Martinez, M., Pullinger, C., and Smith, M.E., 2001, Assessment of landslide hazards resulting from the February 13, 2001, El Salvador earthquake: U.S. Geological Survey Open-File Report 01-119, $20 \mathrm{p}$.

Bucknam, R.C., Coe, J.A., Mota, A., Godt, J.W., Tarr, A.C., Bradley, L.A., Rafferty, S., Hancock, D., and Dart, R.L., Landslides triggered by Hurricane Mitch in GuatemalaInventory and discussion: U.S. Geological Survey Open-File Report 01-443, 40 p., 23 plates.

Cannon, S.H., Haller, K.M, Ekstrom, I., Schweig, E.S. III, Devoli, G., Moore, D.W., Rafferty S.A., and Tarr, A.C., 2001, Landslide response to Hurricane Mitch rainfall in seven study areas in Nicaragua: U.S. Geological Survey Open-File Report 01-412-A, 17 p., 7 plates.
Luz Barrios (GESAL) for their initial assistance in identifying regions of El Salvador where the hurricane has caused damage and landslides. We also benefited from the assistance of R. Willie Rodriguez, Paul Hearn, Verne Schneider, and Nancy Zeigler of the USGS, who provided organizational and logistical support throughout the project. Finally, but not least, we thank Eleanor Omdahl, Margo Johnson, and Pamela Detra for their expert assistance in preparing the final products for this projects.

Ferraro, R., Vicente, G., Ba, M., Gruber, A., Scofield, R., Li, Q., and Weldon, R., 1999, Satellite techniques yield insight into devastating rainfall from Hurricane Mitch: Eos [Transactions, American Geophysical Union], v. 80, no. 43, p. 505, 512, and 514 .

Hellin, J. and Haigh, J., 1999, Rainfall in Honduras during Hurricane Mitch: WEATHER, v. 54, p. 350359.

Harp, Edwin L., Hagaman, Kirk W., Held, Matthew D., and McKenna, Jonathan P., 2002, Digital inventory of landslides and related deposits in Honduras triggered by Hurricane Mitch: U.S. Geological Survey Open-File Report 02-61, 14 p., 20 plates. 
Jibson, R.W., and Crone, A.J., 2001, Observations and recommendations regarding landslide hazards related to the January 13, $2001 \mathrm{M}-7.6 \mathrm{El}$ Salvador earthquake: U.S. Geological Survey Open-File Report 01-141, 19 p.

Lott, N., McCown, S., Graumann, A., and Ross, T., 1999, Mitch-The deadliest Atlantic hurricane since 1780:

http://lwf.ncdc.noaa.gov/oa/reports/ mitch/mitch.html.
Molnia, B.F., and Hallam, C.A., 1999, Open skies aerial photography of selected areas in Central America affected by Hurricane Mitch: U.S. Geological Survey Circular 1181, $82 \mathrm{p}$.

Weber, H.S., Wiesemann, G., Lorenz, W., and Schmidt-Thome, M, 1978, Mapa geológico de República de El Salvador/América Central:

Publicado por la Bundesanstalt und Rohstoffe, Hannover, Germany, scale: 100,000, 6 oversize plates. 